\title{
FOUR TESTS FOR LIABILITY IN TORTS
}

\author{
GUIDO CALABRESI and ALVIN K. KLEVORICK*
}

$\mathrm{O}$

I. INTRODUCTION and of products liability law especially-is that the courts have apparently had an unusual degree of difficulty in explaining the basis of liability. Product defect has never provided an illuminating starting point for analysis, and when it is defined to include design defects, it helps even less. Taken literally, product defect would seem to imply liability for any and all injuries that are causally linked to the product. What product could not have been designed so that a particular injury would have been avoided, at least if cost avoidance (including inconvenience and lack of effectiveness of the product) were paid no heed? Yet, as has often been pointed out, ${ }^{1}$ that is not the thrust of strict product liability.

When courts have tried to limit this seemingly too open-ended basis of liability, however, they have been singularly vague. Words such as "expectations" are introduced, ${ }^{2}$ but expectations are rarely much more than

\footnotetext{
* Dean and Sterling Professor of Law, Yale University Law School, and Professor of Law and Economics, Yale University. The authors would like to acknowledge the helpful comments of participants in the Conference on Critical Issues in Tort Law Reform: A Search for Principles, held at Yale Law School, September 21-22, 1984, participants in the Law and Economics Seminars at Stanford University and the University of Southern California Law Center, and their colleagues at Yale University Law School. They are also grateful for the research assistance of Jonathan Bain, Stephen Fishbein, and Thomas Hungar.

' See, for example, John W. Wade, On the Nature of Strict Tort Liability for Products, 44 Miss. L. J. 825 (1973); David G. Owen, Rethinking the Policies of Strict Products Liability, 33 Vand. L. Rev. 681 (1980).

2 For example, Barker v. Lull Eng'g Co., 20 Cal. 3d 413, 143 Cal. Rptr. 225, 573 P.2d 443 (1978) (one of two tests); Mathews v. Campbell Soup Co., 380 F. Supp. 1061, 1065-66 (S.D. Tex. 1974); Heaton v. Ford Motor Co., 248 Or. 467, 435 P.2d 806 (1967); Vincer v. Esther Williams All-Aluminum Swimming Pool Co., 69 Wis. 2d 326, 352, 230 N.W.2d 794, 798 (1976); see generally Restatement (Second) of Torts $\$ 402 \mathrm{~A}$, comment i (1964).
}

[Journal of Legal Studies, vol. XIV (December 1985)] 
circular. People will expect products to be absolutely safe if they are told they can so expect, until experience proves to the contrary, and they will not hold such expectations if they are told they cannot. Furthermore, if expectations are meant to imply that custom of the trade or "state of the art" is a defense, then strict liability is less strict than was old-time negligence, which, even in Holmes's day, recognized that what was actually done at best could be evidence of what ought to be done but that it could not conclude the issue of what was reasonable behavior. ${ }^{3}$

At other times, courts have spoken as if liability should apply when the risk entailed by the use of the product is unreasonable, even if the behavior of the producer was not. ${ }^{4}$ This seems to suggest that costs of accident avoidance are relevant to the issue of liability, so that risk-benefit analysis remains at the core of tort law. At the same time, this locution tries to distinguish "no-fault" product liability from the traditional cost-benefit test-the Learned Hand negligence calculus. ${ }^{5}$ Unfortunately, "unreasonableness" in a product is not self-defining. Indeed, if reason is a characteristic of humans (and, as some would have it, of animals), it is almost a contradiction in terms when applied to things. Trees may have standing, ${ }^{6}$ and products too, but it seems unlikely that they are ever reasonable or unreasonable.

This is not to say that court pronouncements that use these "tests" are without content; far from it. Courts are, we believe, reaching for two quite definite and distinct bases of liability when they use terms like "expectations" and "product reasonableness" in the context of no-fault liability. In this paper, we shall propose an interpretation of those "tests," those bases of liability, and examine some of the consequences of using each test. We shall do this, in part, by contrasting the expectations and product reasonableness tests with the traditional Learned Hand calculus of negligence. Much of our time, however, will be spent on the product reasonableness test, which we shall call the ex post Learned Hand test, because the traditional Learned Hand test and the "strict liability" test, which we shall identify with the expectations test, have

3 Texas \& Pac. Ry. Co. v. Behymer, 189 U.S. 468 (1903); Wabash Ry. Co. v. McDaniels, 107 U.S. 454 (1883); The T. J. Hooper, 60 F.2d 737 (2d Cir. 1932), cert. denied, 287 U.S. 662 (1932).

${ }^{4}$ See Restatement (Second) of Torts, supra note 2, § 402A(1); Barker v. Lull Eng'g Co., 20 Cal. 3d 413, 143 Cal. Rptr. 225, 573 P.2d 443 (1978) (one of two tests); Beshada v. JohnsManville Prods. Corp., 90 N.J. 191, 447 A.2d 539 (1982); Heaton v. Ford Motor Co., 248 Or. 467, 435 P.2d 806 (1967); Caterpillar Tractor Co. v. Beck, 593 P.2d 871 (Alaska 1979).

5 See Conway v. O'Brien, 111 F.2d 611 (2d Cir. 1940), rev'd on other grounds, 312 U.S. 492 (1941); United States v. Carroll Towing Co., 159 F.2d 169 (2d Cir. 1947) (L. Hand).

${ }^{6}$ See Christopher D. Stone, Should Trees Have Standing?-Toward Legal Rights for Natural Objects, 45 S. Cal. L. Rev. 450 (1972). 
already been defined and analyzed. ${ }^{7}$ We shall also show that there are, in fact, two different ways in which the expectations or strict liability test can be applied. The difference depends on whether only the information available at the time of the accident is used in determining where to place liability. Hence, as we shall see, there are actually three logically possible rules of no-fault liability in addition to the traditional fault test.

\section{Three Tests (And Their Mirror Images)}

1a. The loss lies on the injured victim unless the injurer knew or should have known, at the time he or she acted, that accident avoidance by him or her was cheaper than the cost of the accident. Roughly speaking, this is the classic Learned Hand test for negligence liability. ${ }^{8}$ Words like "cost" and "cheaper" create difficulties (as did the actual words the great judge used). For example, do they mean costs to the particular parties or do they mean, as they clearly should, social costs? Do they take into account only physical and economic costs or, again as they clearly should, moralisms and emotional "costs" as well (whether or not these should then be compensated)? Is the injurer's behavior to be evaluated in the light of what the victim actually did or in the light of what the victim should have done? Such questions remain; but by and large, the test is well understood.

1b. The loss lies on the injurer unless the victim knew or should have known, at the time he or she acted, that accident avoidance by him or her was cheaper than the cost of the accident. This, which Calabresi and Hirschoff have called the reverse or mirror image Learned Hand test, ${ }^{9}$ is, of course, exactly the same test as the Learned Hand test but with a different initial entitlement. It begins with the premise-as unexamined as its opposite usually is in the Learned Hand test-that losses should lie on injurers and alters that status only for a good reason-namely, victim negligence. Although this is often termed strict liability with a contributory negligence defense,${ }^{10}$ it is conceptually the old fault test with a different starting point.

${ }^{7}$ Guido Calabresi \& Jon T. Hirschoff, Toward a Test for Strict Liability in Torts, 81 Yale L. J. 1055 (1972).

8 "The degree of care demanded of a person by an occasion is the resultant of three factors: the likelihood that his conduct will injure others, taken with the seriousness of the injury if it happens, and balanced against the interest which he must sacrifice to avoid the risk." Conway v. O'Brien, 111 F.2d 611, 612 (2d Cir. 1940), rev'd on other grounds, 312 U.S. 492 (1941). Compare Richard A. Posner, A Theory of Negligence, I J. Legal Stud. 29 (1972).

9 Calabresi \& Hirschoff, supra note 7, at 1058.

10 See, for example, John Prather Brown, Toward an Economic Theory of Liability, $2 \mathrm{~J}$. Legal Stud. 323 (1973); Richard A. Posner, Economic Analysis of Law 139 (2d ed. 1977). 
There may be good reasons for this starting point, as there may be good reasons for the traditional starting point-inherited from the nineteenth century ${ }^{11}$ - which left losses on the victim unless the injurer was at fault. But these reasons are generally not examined, and the form of the key question under the reverse Learned Hand test is the same as that under its more traditional counterpart: namely, whether the actor knew or should have known at the time of acting that his or her behavior would fail a social cost-benefit analysis as struck by some agent of the state (whether court, jury, or legislature).

2a. The loss lies on the victim unless the injurer is in a better position to decide whether avoidance of the accident would be cheaper than the cost of the accident. This, which, together with its converse, Calabresi suggested some time ago as the test for strict liability, ${ }^{12}$ does not ask whether the actor, at the time of acting, would fail a cost-benefit test. Instead, it asks whether the actor is better placed than others to make the cost-benefit analysis and to act on the analysis once made. The issue is not how the balance is struck but who is best placed to strike and to act on the balance. If one actor is best able to make the cost-benefit analysis but another is most able to take the required actions, then application of the test itself necessitates a choice among those on whom liability might be placed. Once again, the problems of what "cost" means (social or private, moral or just economic-physical, etc.) remain. ${ }^{13}$ But once again these are to the side of the issue on which we are focusing in this paper.

$2 \mathrm{~b}$. The loss lies on the injurer unless the victim is in the best position to decide whether avoidance of the accident would be cheaper than the cost of the accident. This is the same test as $2 \mathrm{a}$ with the initial presumption or starting point altered. ${ }^{14}$ In practical terms, it would mean a pre-

"This "traditional" set of entitlements, whose ascendancy roughly coincided with the Industrial Revolution, Brown v. Kendall, 60 Mass. (6 Cush.) 292 (1850), was itself preceded by a regime of strict liability, at least under the action in trespass. See, for example, The Case of Thorns, Y.B. Mich. 6 Edw. 4, f. 7, pl. 18 (1466); see generally Lawrence M. Friedman, A History of American Law 409-10 (1973). For a mildly revisionist view of the putative evolution from strict liability to negligence and back again, see Robert L. Rabin, The Historical Development of the Fault Principle: A Reinterpretation 15 Ga. L. Rev. 925 (1981).

12 Calabresi \& Hirschoff, supra note 7. See also Guido Calabresi, The Decision for Accidents: An Approach to Nonfault Allocation of Costs, 78 Harv. L. Rev. 713, 726-27 (1965) (discussing best cost evaluator in the context of initial loss bearing).

13 See generally Guido Calabresi, The Costs of Accidents (1970); and Guido Calabresi, Ideals, Beliefs, Attitudes, and the Law (1985).

14 In Strict Liability (Calabresi \& Hirschoff, supra note 7), Calabresi conflated tests 2a and $2 \mathrm{~b}$. We have each come to the conclusion that it is better to separate them. Calabresi originally conflated them because he assumed that the choice of the starting point, of the 
sumption of injurer liability (whether statutory, as in workers' compensation, or common law, as in ultrahazardous activity liability) ${ }^{15}$ but with a defense of assumption of risk in its first sense of victim knowledge and acceptance of risks. ${ }^{16}$

initial presumption, was based on which actor-injurer or victim-could best strike the cost-benefit balance. On that assumption, it seemed odd to create an initial presumption of liability on the basis of who can best choose between safety and accident costs and then to reverse the presumption on the basis of precisely the same data. But this understates the richness of the choices involved. In the first place, the initial presumption may be based on who generally is believed to be best able to strike the balance (employer in workers' compensation, blaster in ultrahazardous activities, victim in ordinary injuries); and the reversal may be based on who in the specific case, or on the basis of specific facts, can do so. Thisfor example-would explain the applicability of the defense of assumption of risk in ultrahazardous activity cases. See, for example, Worth v. Dunn, 98 Conn. 51, 118 A. 467 (1922); Muller v. McKesson, 73 N.Y. 195 (1878). The different level of generality at which the same question is asked may yield a different answer. In the second place, and probably more important, there is no reason to assume that the initial presumption is based on relative knowledge and capacity to avoid costs. It may equally well be based here (or in the choice between a Learned Hand and a reverse Learned Hand test) on wealth distribution considerations. If these are meant to be ultimately decisive, that is the end of the matter and probably also of tort law as a system for deciding individual cases. If, instead, choosing between safety costs and accident costs remains important to the placement of losses in torts, an initial presumption as to loss placement based on distributional grounds may be overcome when the other party is noticeably better suited to help society reduce the sum of accident and safety costs. One may believe that the traditional negligence calculus was based on initial distributional judgments implying victim loss bearing was desirable but that even the nineteenth century was willing to overcome these judgments when injurer fault showed accident cost reduction by injurers to be worthwhile. Similarly, one could today make the same distributional judgment yet shift liability to injurers if they are best suited to decide whether avoidance is worth it (2a). Alternatively, one could decide that injurers (for example, product manufacturers) are, for distributional reasons, best suited to bear accident losses and yet override that presumption when victims use products in unusual ways, ways whose risks and benefits they could best evaluate (2b).

15 As to workers' compensation, see Richard A. Epstein, The Historical Origins and Economic Structure of Workers' Compensation Law, 16 Ga. L. Rev. 775 (1982). As to ultrahazardous activity, see, for example, Cities Serv. Co. v. State, 312 So. 2d 799 (Fla. Dist. Ct. App. 1975) (slime dam); Spano v. Perini Corp., 25 N.Y.2d 11, 302 N.Y.S.2d 527, 250 N.E.2d 31 (1969) (blasting); Exner v. Sherman Power Constr. Co., 54 F.2d 510 (2d Cir. 1931) (blasting); Yommer v. McKenzie, 255 Md. 220, 257 A.2d 138 (1969) (gasoline tanks). See generally Restatement (Second) of Torts $\$ 520$ (1977).

16 "Assumption of risk" has traditionally carried two distinct meanings. In its primary sense, it simply connoted that the defendant owed no duty to the plaintiff. This doctrine evolved from the common-law action of a servant against his master. The master owed a duty to provide a reasonably safe workplace. $3 \mathrm{C}$. B. Labatt, Commentaries on the Law of Master and Servant, $\$ 1186 a$ (2d ed. 1913). If he discharged that duty, the master was not liable for damages due to the inherent risks that remained-the worker was in a better position to evaluate and avoid these risks. Priestley v. Fowler, 3 M. \& W. 1, 150 Eng. Rep. 1030 (1837); Thomas v. Quartermaine (1887) 18 Q.B.D. 685. In its secondary sense, "assumption of risk" connoted that the plaintiff had negligently assumed a known risk; as such, this was simply a synonym for contributory negligence. See generally Meistrich v. Casino Arena Attractions, Inc., 31 N.J. 44, 155 A.2d 90 (1959); Fleming James, Jr., Assumption of Risk: Unhappy Reincarnation, 78 Yale L. J. 185 (1968). 
3a. The loss lies on the injured victim unless (after the accident), at the time a social decision maker strikes the balance, accident avoidance by the injurer is found to be cheaper than the cost of the accident. This, which we call the ex post Learned Hand test, is, we would suggest, what a number of courts are reaching for when they talk about "reasonableness" of the product rather than of the producer. ${ }^{17}$ It is not a fault-based test (as the courts say, correctly) ${ }^{18}$ because what the injurer knew or should have known at the time of acting is irrelevant. To speak of "fault" under such circumstances would be bizarre. ${ }^{19}$ This ex post test is, nevertheless, categorically different from the "strict liability" tests described in $2 a$ and $2 b$.

Unlike the strict liability tests, which ask only who is best suited to strike a cost-benefit balance and then place the loss on that party or parties, the ex post Learned Hand test retains a fundamental aspect of the traditional negligence test. Under it-as under the fault test-a collective, social body decides whether a risk is worth taking, whether safety makes sense or is too costly. But, unlike "fault," this third test makes the decision as of the time the question is put to the social decision maker and not as of the time the actor acted. The striker of the balance may-as in the fault test-be a court, a jury, an administrative agency, or a legislature, but the facts it considers are not those available (or that ought to have been available) to the injurer at the time he or she chose to act as he or she did. They include, instead, all those facts that have come to light since. Liability is placed on the injurer not because he or she ought to have chosen safety rather than risk when he or she acted but because now the action taken is found to be too costly, given its risks.

3b. The loss lies on the injurer unless (after the accident), at the time a social decision maker strikes the balance, accident avoidance by the victim is cheaper than the cost of the accident. This is simply the reverse or mirror image of 3a. It starts out by placing losses on injurers but

\footnotetext{
17 See note 4 supra. Note the similarity to nuisance, where the focus is on the "reasonableness" of the interference with the plaintiff's use of his land rather than on the reasonableness of the defendant's conduct. See note 63 infra.

18 Beshada v. Johns-Manville Prods. Corp., 90 N.J. 191, 447 A.2d 539 (1982); Barker v. Lull Eng'g Co., 20 Cal. 3d 413, 143 Cal. Rptr. 225, 573 P.2d 443 (1978) (one of two tests). But see Feldman v. Lederle Laboratories, 97 N.J. 429, 479 A.2d 374 (1984), a pharmaceuticals failure-to-warn case, in which the New Jersey Supreme Court sharply limited Beshada by restricting its holding to the particular circumstances of the case.

19 It would be even more bizarre than to speak-as is commonly done-of fault by someone who is incapable of living up to the behavior of the ordinary reasonable person. See, for example, Kuhn v. Zabotsky, 9 Ohio St. 2d 129, 224 N.E.2d 137 (1967) (while insanity may be a defense to criminal charges, it does not mitigate fault in a tort action); Vaughan v. Menlove, 3 Bing. (N.C.) 468, 132 Eng. Rep. 490 (C.P. 1837).
} 
overrides that initial starting point if, on the basis of data available at the time of decision making, the decision maker believes that the victim's behavior is not worth its risks. Like 3a, this test is concerned neither with whether the actors (victims in this case) knew or should have known this when they acted nor with the reasonableness of what they did as assessed at the time they acted.

\section{A FOURTh Test}

This review of the bases of liability on which courts have recently relied in products liability cases, and in particular the contrast between the ex ante and ex post Learned Hand rule, suggests that there is a missing test. At least it suggests that courts and commentators have not been sufficiently clear about the temporal aspect of the test for strict liability. Just as one can decide on an ex ante or an ex post basis whether a party should have acted as he or she did, one can exclude or include information acquired since the time of an accident when deciding where responsibility should rest for performing and acting on the cost-benefit analysis. The social decision maker can ask, Given what was known when the accident took place, who was in a better position to decide whether accident avoidance costs would have been lower than the accident cost itself? or, Given what we know now, after the accident, who is in a better position to make and act on such a cost-benefit analysis? Henceforth, we shall identify answers to the former question with rules $2 \mathrm{a}$ and $2 \mathrm{~b}$ and refer to answers to the latter as rules $4 a$ and $4 b$.

This is not a matter of simply finding and filling "empty boxes." On the contrary, noting the logical possibility of this fourth test, or at least the choice available to a court that would impose "strict liability," as we are defining it, serves the important purpose of illuminating two different dimensions of the bases invoked in products liability. The first is the question of whether the balance of safety costs and accident costs is struck by a collective body or by one of the actors. In the latter case, the social institution-judge, jury, administrative body, or legislaturechooses the actor best suited to perform the cost-benefit calculation but stops there. In the former, the collectivity's "representative" must also determine what each actor should and should not have done. The second dimension of the several tests concerns the information used in making the decision. Does the decision maker use only what was known or should have been known when the accident occurred, or does it allow itself to take notice of what has been learned between the time of the accident and the time of decision?

It is, perhaps, convenient to conceptualize the choice of a products 
TABLE 1

\begin{tabular}{|c|c|c|}
\hline & \multicolumn{2}{|c|}{ Mode of Performing the Cost-Benefit Analysis } \\
\hline & Social Decision & Parties' Decision \\
\hline $\begin{array}{l}\text { Use information } \\
\text { available at time of accident } \\
\text { Use information } \\
\text { available at time of trial }\end{array}$ & $\begin{array}{l}\text { Ex ante Learned Hand } \\
\text { Ex post Learned Hand }\end{array}$ & $\begin{array}{l}\text { Ex ante strict liability } \\
\text { Ex post strict liability }\end{array}$ \\
\hline
\end{tabular}

liability test-ignoring for the moment the mirror image possibilities-as the selection of a cell from Table 1. To determine why a court (or a society) might choose one test rather than another, it is necessary to ask about both the choice between collective and individualized decision making and the choice between updating the information base and restricting oneself to what the parties knew or should have known at the time they acted.

\section{Burdens of Proof and Mixtures of Tests}

Before we ask why courts would want to use one or another of these tests, two other points bear comment. First, it is important to separate the issue of burdens of proof from the issue of which test is chosen. Second, we should emphasize that courts can-and do-combine the tests in quite complex ways.

It may seem that the specified tests do no more than describe who bears the burden of convincing a social decision maker on the issue of whether avoidance or risk taking was or is worthwhile. That, we believe, is not correct. Indeed, under each test analogous issues of who bears the burden still remain. For example, under the traditional Learned Hand test (1a), the loss may lie on the victim unless the injurer knew or ought to have known (at the time he or she acted) that risk avoidance was worthwhile, but the burden of showing whether such "negligence" existed can be placed on the injurer rather than on the victim, as it traditionally has been. ${ }^{20}$ The same issue of placing the risk of nonpersuasion arises for the strict liability tests ( 2 and 4 ) and under the ex post Learned Hand test (3), as courts have well recognized. Those that have invoked the ex post

\footnotetext{
${ }^{20}$ Indeed, this is what happens in res ipsa loquitur cases, at least in those jurisdictions that regard res ipsa as shifting the burden of going forward, for example, Hammond $v$. Scot Lad Foods, Inc., 436 N.E.2d 362 (Ind. App. 1982); Hyder v. Weilbaecher, 54 N.C. App. 287, 283 S.E.2d 426 (1981); Newing v. Cheatham, 15 Cal. 3d 351, 124 Cal. Rptr. 193, 540 P.2d 33 (1975), or, indeed, the risk of nonpersuasion, for example, Toussant v. Guice, 414 So. 2d 850 (La. App. 1982).
} 
Learned Hand test have frequently chosen rule $3 \mathrm{a}$ with the burden of proof on the injurer: losses remain on victims unless on the basis of current ex post data the risk taken by the injurer fails a cost-benefit test, but the injurer bears the burden of showing that his or her behavior can pass such an ex post test. ${ }^{21}$

The placement of such burdens is, of course, crucial-at least as critical as the choice of test and the choice of starting point under the test chosen. But it is important to distinguish three different, and all fundamental, decisions that must be made in assigning accident costs: (1) the test for liability ("negligence" versus "ex ante strict liability" versus "ex post unreasonable risk" versus "ex post strict liability"); (2) the starting point under each test (victim loss bearing unless the injurer fails the test chosen versus injurer loss bearing unless the victim fails the test chosen); and (3) the placement of the burden (victim must convince the trier of fact that the injurer fails the test chosen and that the victim passes it versus injurer must convince the trier of fact that the victim fails the test chosen and that the injurer passes it). ${ }^{22}$

The second point to emphasize is that the tests can be, and are, used in mixed ways by courts. ${ }^{23}$ Moreover, these mixtures are made more complex by the possibility of adding different burdens of proof. Thus courts or legislatures may choose the starting point of injurer liability, not because of distributional concerns, but because they believe that by and large

\footnotetext{
21 See, for example, Barker v. Lull Eng'g Co., 20 Cal. 3d 413, 143 Cal. Rptr. 225, 573 P.2d 443 (1978). The Court's reasoning echoed the rationale for shifting the burden in res ipsa loquitur cases: "Because most of the evidentiary matters which may be relevant to the determination of the adequacy of a product's design under the 'risk-benefit' standard ... involve technical matters peculiarly within the knowledge of the manufacturer, we conclude that once the plaintiff makes a prima facie showing that the injury was proximately caused by the product's design, the burden should appropriately shift to the defendant to prove, in light of the relevant factors, that the product is not defective." 20 Cal. $3 \mathrm{~d}$ at 431 , 573 P.2d at 455. Compare Buckelew v. Grossbard, 87 N.J. 512, 526, 435 A.2d 1150, 1157 (1981) (doctrine of res ipsa is grounded in the "sound procedural policy of placing the duty of producing evidence on the party who has superior knowledge or opportunity for explanation of the causative circumstances"'). See generally Gary T. Schwartz, New Products, Old Products, Evolving Law, Retroactive Law, 58 N.Y.U. L. Rev. 796, 828-36 (1983) (the length of time that elapses between manufacture and injury-and, hence, the party who has better "access to information" - should be a primary consideration in allocating burdens of proof as between manufacturer and consumer).

${ }^{22}$ Of course, the burden for different issues can be placed on different parties.

23 One of the more pronounced examples of this tendency is Barker v. Lull Eng'g Co., 20 Cal. 3d 413, 143 Cal. Rptr. 225, 573 P.2d 443 (1978). In Barker, the court held that a manufacturer could be held liable for design defect if either (1) the product fails to live up to ordinary consumer expectations (essentially a strict liability rationale) or (2) the marginal benefits of the product's design fail to outweigh its marginal risks (an ex post test). A similar mixed test was adopted in Caterpillar Tractor Co. v. Beck, 593 P.2d 871 (Alaska 1979).
} 
injurers are best placed to decide what safety measures are worth taking (essentially a strict liability or type-2 or -4 test). They may, however, permit that starting point to be reversed if it can be demonstrated that, even on the basis of ex post data, what the injurer did was reasonable (an ex post Learned Hand or type-3 test). They may also choose to reverse the starting point if the victim acted in a way that could be shown to be faulty at the time he or she acted (a traditional negligence or type-1 test). Finally, they can put on the injurer the burden of demonstrating, and of convincing the trier of fact, that either of the exceptions to the starting point holds, or they can require the victim to demonstrate that the exceptions do not apply.

Under the circumstances, it is not surprising that it is often quite hard to tell just what the courts or legislatures are up to in such cases. This is especially so since they are not likely to focus on which of these things they are doing or even to use language that can immediately tell us what choices they have made. Hence, there is all the more reason to examine further the advantages and disadvantages of the tests that have been used and more specifically to examine the ex post Learned Hand test, which has been analyzed least and is probably the most controversial possibility. ${ }^{24}$

\section{The Ex Post Learned Hand Test Analyzed}

At first blush, the ex post Learned Hand test would seem to assign the loss in virtually every case to the party who, to avoid loss bearing, must show that its conduct was reasonable ex post. But that is not what happens when courts use the test. The conclusion drawn from a first impression of the test, or from its literal meaning, is overly hasty and rests on an improper understanding of what the test entails. The following examples demonstrate this and in doing so point the way to the true meaning of the test.

Suppose Marshall is driving his car at twenty-five miles per hour in a thirty-mile-per-hour speed zone, and suppose Taney, a child too young to be contributorily negligent, darts out from behind a parked car and is hit and grievously hurt. Suppose finally that, had Marshall been driving at twenty miles an hour, he would have been able to avoid the accident. Under the traditional Learned Hand test, there would usually be no negligence on Marshall's part. If, however, one were to employ the ex post

${ }^{24}$ For a historical invocation of the ex post test in a different setting, see Mayor of New York v. Lord, 18 Wend. 126 (N.Y. 1837). The court employed the hindsight test in deciding whether to hold the City liable for the destruction of a building while fighting a fire when the destruction proved to be unnecessary. 
test and apply it literally, it is hard to see how Marshall could avoid liability. The "cost" of driving at twenty miles per hour in a thirty-mile zone may, generally speaking, be too high to be justified. (The safety cost is greater than the accident cost discounted by the risk of occurrence.) That is why no traditional negligence would exist. But, except in extraordinary circumstances, the cost of driving twenty miles an hour for the few seconds necessary to avoid this accident would be far less than the accident costs such momentary slowing down would have avoided.

To put it another way, if Marshall knew that Taney would dart out at the moment he did and that by driving at twenty miles per hour for a few seconds Marshall could avoid hitting Taney, surely Marshall would be duty bound to avoid the accident. If he did not slow down, given that knowledge, at a minimum he would fail the traditional Learned Hand test and would without doubt be liable. ${ }^{25}$ Yet, taken literally, it is just such ex post knowledge that the third test would seem to ask the decision maker to consider in determining whether the behavior (though not faulty when engaged in) was, in retrospect, worthwhile. We now know that driving at twenty miles per hour for those few seconds would have avoided Taney's injury. How can we deny that Marshall's driving at twenty-five miles an hour on this occasion was unreasonably risky ex post, even if eminently justified ex ante?

The same problem can be seen if one looks at the area of product injuries, where the ex post test has been applied most frequently. ${ }^{26} \mathrm{Mar}$ shall sells Taney a headache remedy. It, unlike other available pills, is virtually 100 percent effective-and this fact is important to Taney, for whom headaches would be highly inconvenient. But the pill causes a severe allergic reaction in one out of $\mathbf{2 0}$ million users. Adequate warning of the possibility of allergic reactions is conveyed to Taney and understood by him.

There is no negligence on Marshall's part. Moreover, it is highly unlikely that type-2 strict liability would be placed on Marshall. Taney is almost certainly in the best position to decide between the cost of a headache to him and the risk of allergic reaction and hence whether to opt for this as against other, less effective, remedies. Suppose, however, that Taney turns out to be the one in $\mathbf{2 0}$ million who suffers the allergy. Ex post the product was unreasonably risky to him. Had it been known that he would be injured, the slight risk of failing to relieve the headache,

\footnotetext{
25. This would be the outcome except in fanciful cases in which those very seconds were more valuable than Taney's damages.

${ }^{26}$ See generally W. Page Keeton, Products Liability-Design Hazards and the Meaning of Defect, 10 Cum. L. Rev. 294 (1979); Wade, supra note 1.
} 
which would be entailed by use of other available remedies, would have been well worthwhile. Does not Marshall's product, therefore, fail the ex post Learned Hand test?

The answer, it seems clear, is no. The reason is that in this case, as in the hypothetical case of the automobile, the facts learned as a result of the accident or after the accident in no way altered our knowledge or judgment about future risks. ${ }^{27}$ If it was sensible to drive at twenty-five miles per hour before Marshall struck Taney, it remains sensible for latter-day Marshalls to drive at twenty-five miles per hour. Nothing learned from the accident or thereafter causes us to consider that such behavior creates unreasonable risks of future accidents. We learned nothing that would lead us to believe that darting out from cars is more frequent or dangerous than we had believed or to know better when other Taneys might dart out in front of cars. The same is true as to the headache remedy case. We now know that Taney is allergic. But we learned nothing from his allergy that should guide our subsequent behavior except that he should not use that particular pill. As to the world at large, what was a reasonable product risk before remains reasonable now.

The case would look very different if instead we had learned-as a result of Taney's allergic reaction or independently of it but still after the injury - that certain categories of people were highly likely to be allergic, one in 100 , say. It would also be different if we had discovered after the accident that a simple skin test-easily undergone before taking the pillcould determine who was allergic. Finally, it would a fortiori be different if we had learned that the one in $\mathbf{2 0}$ million allergic reaction was simply an unusual outward sign of a catastrophic hidden disease that hit a large proportion of users of the pill, most of whom-unlike Taney-showed no immediate allergic reaction, but all of whom ultimately became sick. In all these cases, in which the data learned ex post give useful guidance for altering future behavior, it is possible to say that the product is "unreasonably risky." It is possible, in other words, to say that, though what the producer/actor did was reasonable at the time he or she acted, it would be unreasonable for him or her to behave in a similar manner subsequently. This, we suggest, is the essence of the ex post Learned Hand test as it has been applied.

The ease with which we can distinguish in our hypothetical cases between situations in which accidents do provide new information about the risks and those in which they do not conceals a difficult issue of fact finding in actual cases. How does the trier of fact determine that the urn of risks is different from what it was previously believed to be and that the

\footnotetext{
27 In the examples, we assumed that the accident's occurrence did not induce a divergence between the prior and posterior probabilities of harm.
} 
accident was not simply an unfortunate draw from the old urn of risks rather than the other way around? Application of the ex post Learned Hand test clearly requires going beyond the individual instance to the underlying probability distribution of potential harms. This requirement imposes more of a burden on the decision maker than does the question posed by the ex ante Learned Hand test. On the other hand, the ex ante test is more difficult for the trier of fact because it requires reconstruction of what was known or knowable at some time in the past, while the ex post test depends on what is known today.

Why should we place losses on actors who behaved reasonably if and only if their behavior would seem unreasonable on the basis of new data? And why should we do this only in cases in which the new information tells us something about future risks of accidents? An analogous relationship among past actions, new data, and future risks exists in traditional causation tests for tort liability. Looking at that relationship may help us further to understand what the ex post test means and why it might sometimes be employed.

Traditionally, for liability to lie in tort, a requirement of causation had to be met. ${ }^{28}$ That requirement had several parts. First, the behavior on which liability was predicated generally had to be a but-for cause of the injury. ${ }^{29}$ In addition, that behavior had to be related proximately to the injury. ${ }^{30}$ It was soon noticed, however, that in certain cases of "coincidence," the injurer was found not liable even though the injurer was negligent; but for that negligence no injury would have occurred; and directness of injury and proximity in time and space between defendant behavior and injury were clear. A classic case involved a speeding trolley car. ${ }^{31}$ But for its speeding, the trolley would not have been under a rotten

${ }^{28}$ See generally H. L. A. Hart \& A. M. Honore, Causation in the Law (1959); Restatement (Second) of Torts, supra note 2, § 430.

29 See, for example, Moser v. Texas Trailer Corp., 623 F.2d 1006, 1012-13 (5th Cir. 1980), rehearing denied 630 F.2d 249, aff'd on appeal after remand 694 F.2d 96 (1982); see generally Restatement (Second) of Torts, supra note $2, \S 432$.

${ }^{30}$ See, for example, Palsgraf v. Long Island R.R. Co., 248 N.Y. 339, 162 N.E. 99 (1928); see, generally, Prosser and Keeton on the Law of Torts, $\S 42$ (W. Page Keeton ed., 5th ed. 1984).

31 Berry v. Borough of Sugar Notch, 191 Pa. 345, 43 A. 240 (1899). See also Dombeck v. Chicago, Milwaukee, St. P. \& Pac. R.R. Co., 24 Wis. 2d 420, 129 N.W.2d 185 (1964) (speed of train is not a legal cause of a collision with an auto "merely because the train arrived at the crossing the instant it did while if it had been going slower the car might have safely crossed ahead of it"'); Baker v. Herman Mut. Ins. Co., 17 Wis. 2d 597, 117 N.W.2d 725 (1962) ("[t]his court has never held that excessive or unlawful speed is causal merely because it places the vehicle at a particular place at a particular time. Excessive speed is causal, however, when it prevents or retards the operator, after seeing danger, from slowing down, stopping, or otherwise controlling the vehicle so as to avoid a collision"; 17 Wis. $2 \mathrm{~d}$ at 602,117 N.W.2d at 728). 
tree at the time the tree fell, injuring several people. The injury was certainly direct and close in time and space to the offending behavior and resulted in damages of approximately the same extent as speeding could have been expected to cause to the very same party whom speeding endangered. Why, then, did the court (and do courts generally) refuse to put the loss on the party whose undoubtedly unreasonable behavior was a sine qua non cause of the accident?

In an earlier article, Calabresi pointed out that repetition of the unreasonable behavior described in the trolley example would not increase the chances of a similar accident's occurring in the future. ${ }^{32}$ Whatever one can say about speeding, one cannot say that it increases the chances of trees falling on trolley cars. Calabresi noted that without such a future risk/probability relationship, which he called a "causal link" or "causal tendency," 33 placing the loss on the speeder would not induce future trolley drivers to consider correctly the costs and benefits of speeding. ${ }^{34}$ Imposing such liability, therefore, would in no way help a society to decide when speeding justified its risks and when it did not.

Yet where the behavior in question-for example, speeding-did increase the risk of such injuries, then, as Calabresi noted, liability was commonly imposed, even if the source of danger was unknown at the time the actor acted. ${ }^{35}$ If it were learned that speeding trolley cars created vibrations that significantly increased the chances of rotten trees tumbling just then, liability would almost certainly be assessed. This, he observed,

${ }^{32}$ Guido Calabresi, Concerning Cause and the Law of Torts: An Essay for Harry Kalven, Jr., 43 U. Chi. L. Rev. 69 (1975).

33 Id. at 71 . In a later, more formal treatment of an economic approach to causation in tort law, Shavell refers to this relationship as probabilistic cause. See Steven Shavell, An Analysis of Causation and the Scope of Liability in the Law of Torts, $9 \mathrm{~J}$. Legal Stud. 463, 468 (1980).

34 Calabresi, supra note 32 , at 78.

35 Id. at 88. A strong case for such ex post assessments of cause is made by Mario $\mathrm{J}$. Rizzo, The Imputation Theory of Proximate Cause: An Economic Framework, 15 Ga. L. Rev. 1007 (1981). Rizzo posits that current causation doctrine can best be explained by a theory that imputes perfect knowledge of risk probabilities to the tortfeasor. An action is the proximate cause of an injury if and only if "its objective marginal product in probabilistic terms is higher with respect to [the injury] than that of any other instance of wrongful conduct, intervening events, or the standard environment. Consequently, according to the imputation approach, objective or best-informed probability, but not foreseeability, is important to the determination of proximate cause. What is likely or unlikely to the most perceptive man ('objective') need not be foreseeable or unforeseeable to the reasonable man." Id. at 1008 . This position differs from the conclusion drawn by Shavell, supra note 33. Shavell argues that unforeseeable accidents should be excluded from the scope of liability: an injurer will not make any efforts to avoid the accident if it is unforeseeable, so that inclusion of the accident in the scope of liability has no deterrence value; yet inclusion would increase administrative costs. Id. at 490-91. 
is the lesson of cases such as Polemis, ${ }^{36}$ which on much harder factssince the extent of damage seemed disproportionate to the extent of culpability on which liability was based-held injurers liable even though the requisite causal tendency of the injurer's behavior could only be established ex post.

An important objective of imposing liability for past actions is to affect future behavior, to induce other actors in the future to make correct assessments when they choose between safety and risk. ${ }^{37}$ Correct assessments cannot be fostered by placing liability on a party whose behavioreven viewed ex post-does not increase the probability of the particular injury's occurring, that is, a party whose actions are not causally linked to the particular injury, even if in the particular case the behavior was a butfor cause of the accident. In sharp contrast, however, imposing liability may stimulate correct future risk-benefit assessments when data acquired since an accident lead us to believe that the behavior involved has a tendency to cause such accidents or is dangerous at least in part because it will result in more "like" accidents occurring.

This analysis of causation can help us understand the potential role of the ex post Learned Hand test. The original Taney and Marshall examples were cases in which we learned that Marshall's behavior was, in the given set of circumstances, a but-for cause of Taney's injury. But nothing we learned in those cases led us to want to alter Marshall's future behavior. Of course, if we knew that the precise circumstances would recur, we would want Marshall or Taney to act differently. Similarly, if we knew that the tree would fall at a given moment, we would want the trolley car to slow down (or speed up) so that it would not be there when the tree fell. But by hypothesis, in each case our probability beliefs about the future are unchanged by the accident's occurrence or by what we have learned since then. As a result, a sensible risk-benefit assessment before the accident remains a sensible one now. If the behavior was reasonable when it took place, it remains reasonable now.

On the other hand, where the accident itself or other events since the

\footnotetext{
${ }^{36}$ In re Polemis \& Furness, Withy \& Co. [1921] 3 K.B. 560 (workmen negligently dropped a wooden plank into the hold of a ship, causing a spark that ignited vapors and resulted in the ship's exploding). But compare Overseas Tankship (U.K.) Ltd. v. Morts Dock \& Eng'r. Co. (The Wagon Mound (No. 1)) [1961] A.C. 388 (P.C. Aust.); Republic of France v. United States, 290 F.2d 395 (5th Cir. 1961), cert. denied, 369 U.S. 804 (1962).

37 See generally Calabresi, supra note 13, at 68-94; Posner, supra note 10, at 18-19; but compare Richard A. Epstein, A Theory of Strict Liability, 2 J. Legal Stud. 151 (1973); George P. Fletcher, Fairness and Utility in Tort Theory, 85 Harv. L. Rev. 537 (1972) (tort law as an instrument of corrective justice between the parties to an accident that has already occurred).
} 
accident lead us to reassess substantially the prior risk-benefit relationship, a totally different situation exists. If we now know that the headache pill is much riskier than expected, that five miles an hour in speed make an enormous difference in darting cases, or that rotten trees fall much more frequently when trolleys speed by them, then we do want future behavior to be altered.

Crucial to both the causation cases and the ex post Learned Hand test is the assumption that placing liability for past acts is an appropriate way to affect future behavior. They both view determination of the scope of liability for past behavior as an appropriate instrument for generating socially superior safety choices from similarly situated actors in the future. They assume that such future risk-benefit assessments will be made better if liability decisions take into account data that may be available only after the actor acted than if they consider only what was known at the time the parties chose to do what they did.

This aspect is, of course, what makes the ex post Learned Hand test a nonfault test. It is also what made causation a separate issue from fault. ${ }^{38}$ Nevertheless, the question remains, Why should we think that future riskbenefit assessments will be made better when liability is assigned on the basis of data that were apparently neither known nor knowable when the relevant actions took place? Why in areas of tort law are we not satisfied with applying the data we have obtained from past accidents only prospectively, and stating in future cases-on the basis of such data-that a causal link exists and, analogously, that the manufacture or sale of the offending product is negligent? If we wish to affect future risk-benefit assessments, should not the prospective application of new-found knowledge suffice?

The fact is, of course, that our legal system (in rejecting the traditional Learned Hand test in wide areas of tort law) has concluded that frequently ex post liability that affects future behavior is better than imposing damages only when a social decision maker is able to conclude that the actor knew or ought to have known that his or her behavior was unduly risky at the time the action took place. Nor can this decision be explained simply on the basis of a desire to help victims or on the basis of difficulties of proof. If it were the former, then one would expect that tort law would simply have moved from a Learned Hand test to a reverse Learned Hand test. This would have put the cost burden of all those

38 As one distinguished court put it, "negligence is tested by foresight but proximate cause is determined by hindsight." Dellwo v. Pearson, 259 Minn. 452, 456, 107 N.W.2d 859, 862 (1961). Again, however, it must be hindsight that leads to useful foresight, for otherwise in every accident case the requisite hindsight would be present. 
accidents that were not worth avoiding on injurers instead of on victims. We would have continued to employ the traditional ex ante test but would have used that test to decide which accidents were, in fact, worth avoiding by victims at the time they acted. Since such injurer nonfault liability, with a defense of victim (traditional ex ante) negligence, is anything but the usual rule, it seems that the changes in tort law away from the injurer-favoring Learned Hand test (1a) were not only designed to reverse that bias and favor victims instead-as would a $1 \mathrm{~b}$ test-but implied a rejection of the ex ante test itself.

The same thing can be said-though not quite as clearly-about proof difficulties. If the traditional Learned Hand test made it too hard for victims to show that injurers, at the time they acted, knew or should have known that a risk was too great, then why not simply reverse the burden and require injurers to show that they neither knew nor should have known that the risk was so great? Sometimes this reversal of burden has occurred, ${ }^{39}$ but often the change in tort law has gone well beyond that. If, moreover, the objection to the traditional rule was due both to its proinjurer bias and to proof difficulties faced by victims, one would have expected the change in law to be to a reverse Learned Hand test with the burden on injurers to show that victims ought, ex ante, to have known that accident avoidance was worthwhile. Provictim bias would have replaced proinjurer bias in starting points, and the risk of nonpersuasion would have been put on injurers.

Since this is not what happened, we must conclude that the great recent changes in torts represent more than a shift in underlying distributional biases or a belief that injurers are more capable than victims of showing what the relevant safety and risk potentials are at the time actions occur. To be sure, these two factors have been significant, and they certainly help explain the rise of the complex tests for liability that courts have come to use. We do suggest, however, that these factors cannot by themselves explain the changes.

There must also have been a belief that, whatever the starting point and whoever bore the burden, determining liability on the basis of what was known or ought to have been known at the time of acting provided an inadequate incentive for future risk-safety assessments. There must also have been a belief, in other words, that in wide areas of torts a better risk/ benefit assessment is made, in the future, if liability for past actions is

${ }^{39}$ Often, when the burden has been reversed, it has been in the context of some special relationship, such as common carriers: Note, The Effect of a Presumption of Common Carrier Negligence upon the Burden of Proof, 42 Wash. L. Rev. 273 (1966); or bailees, Soby Constr., Inc. v. Skjonsby Truck Line, Inc., 275 N.W.2d 336 (N.D. 1979). 
based on nonfault tests, whether of the strict liability sort ( 2 and 4 ) or of the ex post Learned Hand sort (3). Before considering why this might be the case, let us compare the way these tests work.

\section{The Tests Compared-The No-Fault Tests versus the Negligence Test}

It may seem that losses are always more likely to be assessed on a party who is held to the strict liability or ex post tests rather than to the traditional negligence test. That, however, is not the case. In practice, liability may result less often under test 1 than under the others, but that is by no means a necessary result. As a matter of theory it is quite possible, for example, that victims rather than injurers would be better positioned to assess risks and benefits even when injurer behavior would fail to meet an ex ante negligence test. Similarly, data that come to light through, or after, an accident can, in theory, as often be used to show that past behavior was in fact worth its risk (even if, at the time, engaging in it would have been abjured by a reasonable person) as to show the reverse. Moreover, and perhaps most important for products liability law today, as we show in the next section, it is by no means clear whether a strict liability test is more or less apt to result in liability than an ex post Learned Hand test is. Let us give examples of each of these points.

The first is the easiest to demonstrate. Consider the traditional assumption-of-risk defense to negligence. This defense applies even though the injurer's behavior at the time of action was unreasonably risky. Such an injurer failed the Learned Hand test and would, in the ordinary course of things, be liable. If, however, the victim-albeit not negligent-is deemed to have been in a better position to assess the risks, the loss is placed on the innocent victim rather than on the negligent injurer. ${ }^{40}$

The point is not to speculate on how often courts may have misused the notion of victims' being in a better position to gauge risks than injurers. ${ }^{41}$

\footnotetext{
40 We say innocent victim because we are talking about assumption of risk in its primary sense and not the version of it that was only another way of describing victim negligence.

41 Such misuse led to severe criticism and nominal decline of the doctrine of assumption of risk. See, for example, Rutter v. Northeastern Beaver Cty. School Dist., 496 Pa. 590, 613, 437 A.2d 1198, 1209 (1981) (listing decisions from nineteen jurisdictions abolishing or vitiating the rule); Meistrich v. Casino Arena Attractions, Inc., 31 N.J. 44, 155 A.2d 90 (1959) (first state to do so). But under other names-whether of "no duty rules" or whatever-the notion that assumption of risk embodies has shown substantial survival power. See, for example, Vargus v. Pitman Mfg. Co., 510 F. Supp. 116 (E.D. Pa. 1981) (continued use of a product with a known defect); Moss v. Atlanta Hous. Auth., 160 Ga. App. 555, 287 S.E.2d 619 (1981) (pedestrian voluntarily using sidewalk known to be hazardous); Akins v. Glens Falls City School Dist., 53 N.Y.2d 325, 441 N.Y.S.2d 644, 424 N.E.2d 531 (1981) (spectator hit by baseball).
} 
Nor is the point to demonstrate that strict liability rules have always played a significant role in torts-whether in establishing injurer loss bearing or victim loss bearing. ${ }^{42}$ It is rather to emphasize that there is no necessary proinjurer or provictim bias in the use of Learned Hand rules as against strict liability rules. The bias-either way-comes from the starting point chosen, where losses lie when it cannot be shown that either party fails the test. Equally important, a bias in results may also occur if in practice, as an empirical matter, one group-injurers or victims-does better on one test than the other. It may be, for example, that by and large injurers are in a better position to make risk-benefit assessments than are victims, while victims are more likely to be ex ante negligent than are injurers. If so, strict liability tests will be more provictim than traditional Learned Hand tests. But as a theoretical matter the reverse is just as possible. And as results based on assumption of risk show, ${ }^{43}$ in particular situations this reversal has occurred.

An analogous relationship between the traditional Learned Hand test (1) and its ex post version (3) is not hard to demonstrate. Suppose that Marshall, a doctor, fails to administer a drug or to take an X-ray and that as a result Taney, a patient, suffers grievous injury. At the time treatment was sought, all reasonable doctors would have given the drug or taken the $\mathrm{X}$-ray because the chances of these procedures helping the patient, though fairly slight, outweighed the then-known or -knowable risks and costs of the procedure. Suppose, however, that it came to be known after the fact that the drug has not uncommon catastrophic side effects or that $\mathrm{X}$-rays, if overused, lead to leukemia. Ex post it would have been reasonable not to employ the procedures since in cases like Taney's the benefits are small and, as we now know, the risks are great. On the traditional Learned Hand test, Marshall should be liable; on the ex post one, he clearly should not!

If courts applying the ex post Learned Hand test (3) followed it precisely, they would also take account of additional benefits of an injurer's action that come to light after an accident as well as recognizing newly learned costs of that action. This is yet another way in which the tradi-

\footnotetext{
42 This has been elegantly shown recently by Robert Rabin. See Rabin, supra note 11. He points out that the proximate cause requirement also served to put losses on nonnegligent victims as against negligent injurers, one might well conclude because distance in time and space made such injurers relatively less good at assessing the risk than the innocent victims.

43 See note 41 supra. A similar result obtains in cases finding an absence of proximate cause. See note 42 supra. Proximate cause can be used to take a "second look," once fault has been established, at whether another party might have been a cheaper cost avoider or indeed whether the cheapest form of safety might have been to alter the level of activity. See Calabresi, supra note 32, at 81-83.
} 
tional ex ante negligence test can be more stringent than its ex post counterpart in imposing liability on an injurer. ${ }^{44}$

Consider also the relationship between the ex ante and ex post Learned Hand tests when the data derived from the accident are not useful in forming judgments about future behavior. Suppose Marshall behaves in a way that is ex ante negligent because his actions entail a risk of catastrophic injury. In fact, in the particular case only a minor injury occurs. Were this injury the only one risked, Marshall's behavior would have been reasonable because, let us assume, safety in such circumstances is quite costly. Ex post, then, what Marshall did was reasonable, whereas ex ante it was not. Yet a court applying the ex post test should find Marshall liable for the minor injury: his behavior is still unduly risky in the future. Marshall's good fortune does not lead us to alter our estimates of the frequency or severity of accidents that result from his type of conduct. That is as irrelevant to the true ex post test as is the fact that reasonable behavior turns out to be catastrophic in a given instance-as, for instance, in our earlier headache remedy example.

Sometimes, of course, courts or juries are swayed by such irrelevant ex post data. That is inevitable but beside the point. As a matter of general application of these tests, the important difference stands between predictably reproducible ex post data and not so reproducible data. On this count too the traditional Learned Hand tests (1) are, as a theoretical matter, no more or less likely to lead to liability than are their ex post cousins (3).

Once again, it may be that in practice one test is usually more demanding than the other and hence more often results in liability. In actuality, ex post data may far more often demonstrate that safety was more worthwhile than it seemed to be ex ante and that risks were far greater than they

\footnotetext{
44 Suppose that a doctor prescribed a drug to treat a severe infection and that at the time it was prescribed it was known that quite undesirable side effects were possible, dizziness being a possibility in 10 percent of all patients. Suppose, moreover, that most physicians refused to use the drug because, on the basis of knowledge available then, they believed the drug to be no more effective than drugs that had no such side effects. Suppose, finally, that the particular patient in our example did experience severe dizziness, which resulted in a serious fall. The fractures he suffered kept him from work for a period of time. Between the time of the injury and the time the case comes to trial, it is learned that the drug is actually much more efficacious in treating the type of infection this patient had-nearly a 100 percent success rate-than it had been thought to be. In short, it may have been ex ante unreasonable for the doctor to give this drug to the patient who subsequently suffered the injuries. But ex post, with the newly acquired knowledge of the drug's success in treating this patient's condition, the costs of not prescribing the drug may exceed the expected costs of having the patient take it. As a result, in this case, the doctor might fail the ex ante Learned Hand test but would pass the ex post Learned Hand test.
} 
"could have been predicted" to be ${ }^{45}$ Rational wagers about whether this is the case-whether made by individuals, firms, or insurers-will depend on subjective judgments about the nature of scientific progress and about what we learn over time about the risks, costs, and benefits of our acts and activities.

There is one set of products liability cases for which one is likely to believe strongly that the ex post Learned Hand test will result in liability more often than the ex ante rule: failure to warn cases. Indeed, it seems that the ex post test applied in such a case will almost always result in a finding of liability. A serious injury has occurred, which alerts us to a hitherto unknown risk that might have been avoided had the consumer been warned. Since warnings are generally financially inexpensive, the producer's failure to warn, given what we now know, constitutes a failure of the Learned Hand test. ${ }^{46}$ But note that, even for any particular case of this type, it may be expensive to provide a warning. Moreover, if the Learned Hand test were correctly applied and account were taken of the social cost of excessive warnings, which may have the effect of numbing consumers' reactions to warnings of serious risks, ${ }^{47}$ ex post application of the rule would not necessarily result in more frequent imposition of liability on producers.

Suppose, however, that we did tend to acquire more "bad news" than "good news" about our risk-safety choices. Then, as an empirical matter, ex post tests (3) would be failed far more often than ex ante tests (1). That may well be the case. If so, it suggests why one might want to employ ex post tests (whether in their provictim or proinjurer versions). For this empirical tendency, if it exists, could suggest that what is knowable ex ante leads systematically to an incorrect risk-benefit analysis and that using ex post data would lead to a better balance between accidents and safety. But more on that later.

45 This will tend to be so systematically in litigated claims since situations in which an accident never occurred generally would not end up in court, regardless of how negligent the actor appeared to be ex ante.

46 See also Malcolm E. Wheeler \& Kenneth J. Kress, A Comment on Recent Developments in Judicial Imputation of Post-manufacture Knowledge in Strict Liability Cases, 6 J. Prod. Liab. 127, 137 (1983).

47 See also id. at 137; Finn v. G. D. Searle \& Co., 35 Cal. 3d 691, 701, 677 P.2d 1147, 1153 (1984); Dunn v. Lederle Laboratories, 121 Mich. App. 73, 80-83, 328 N.W.2d 576, 580-81 (1982); A. D. Twerski, A. S. Weinstein, W. A. Donaher, \& H. R. Piehler, The Use and Abuse of Warnings in Product Liability-Design Defect Litigation Comes of Age, 61 Cornell L. Rev. 495 (1976). 


\section{The Tests Compared-Strict Liability versus Ex Post LEARNED HAND}

The relation between the strict liability tests ( 2 and 4$)$ and the ex post Learned Hand test (3) is more complex. But it is crucial, for it occupies a central place in debates about product liability law today. ${ }^{48}$ In examining that relation we will first show that neither test is necessarily more stringent than the other; neither one is, as a theoretical matter, more likely to lead to liability. This is so whether the strict liability test is applied on an ex ante or an ex post basis. Second, we will indicate what judicial language is linked to each of the tests, to suggest which terminology, in practice, leads to decisions being based on strict liability grounds and which to decisions being based on ex post Learned Hand tests.

Suppose Marshall produces and sells Taney a pharmaceutical. At the time it is sold, it is known to be extremely useful in treating Taney's illness, and no significant side effects are known to exist. No warning is provided. It subsequently turns out that the drug does have very rare but significant side effects, which occur randomly in the population-there is no way to predict who is a potential victim. Taney happened to be significantly injured. Nevertheless, even after these facts become known, it remains the case that the drug is a "reasonable" one. The side effects cannot be controlled without keeping the drug from doing its job, and all agree that its job is an important one, so important that any reasonably phrased warning would be ignored-the patient would be bound to use the drug.

Under the ex post test (3), there is clearly no liability. Under the strict liability test, there may well be. Using the ex ante strict liability test, it all depends on whether, at the time the drug was sold to Taney, Marshall's company was in a better position to evaluate the likelihood of noxious side effects developing than was Taney. If the strict liability test is applied ex post, using the new information that is in hand, the most important choice between safety costs and accident costs may remain with Marshall. This would be the case if, as assumed, a warning would not do much good or if, instead, the possibility exists of developing a somewhat different drug that might avoid the side effects and still be effective. In the latter case, Marshall's company is likely to be the best placed to decide between the cost of seeking the new drug (the safer design) and the cost of paying

48 See, for example, Sheila L. Birnbaum, Unmasking the Test for Design Defect: From Negligence [to Warranty] to Strict Liability to Negligence, 33 Vand. L. Rev. 593 (1980); see also Gary T. Schwartz, The Vitality of Negligence and the Ethics of Strict Liability, $15 \mathrm{Ga}$. L. Rev. 963 (1981). 
for the old drug's damages. Under the strict liability test, the company would be held liable and would in this way be given a clear incentive to decide if such research is worthwhile. ${ }^{49}$

Consider, however, a different situation. Assume that Marshall produces and sells a headache remedy. It is 100 percent effective, is in no way disruptive of sound functioning (for example, it does not induce drowsiness), and at the time of sale is known to have some minor side effects. The capsule carries a warning about these side effects as well as a more general warning explaining that the drug is relatively new and, though it has been tested over five years, there is a possibility that some long-term, as yet unknown, side effects of unknown magnitude may develop. Finally, the warning notes that other remedies exist that are somewhat less effective or that interfere somewhat with one's ability to carry on but that have been used for decades and for which one can virtually exclude the possibility of side effects. Taney cares terribly about relieving his headache and is equally concerned about continuing to work on an important major project in which he is engaged. He decides to use the new capsule, aware of both its known risks and the possibility that unknown ones exist too. It turns out that, when more information becomes known, the headache remedy becomes clearly not worth having. (In one in ten cases, after seven years, one's vision deteriorates seriously; in one in twenty cases, death occurs.) If the ex post Learned Hand test (3) is applied, Marshall is surely liable. In contrast, under the strict liability test, it seems most likely that the loss should lie on Taney whether the test is applied on an ex post basis or only ex ante information is taken into account.

One can readily consider, instead, building materials or herbicides that turn out to cause cancer and by judicious altering of the facts-existence of substitutes, relative knowledge of the advantage of using the substitutes, desirability or necessity of using the product in certain situations even when its risk becomes known, adequacy and effectiveness of warnings-replicate either of the results indicated in the two previous examples. Similarly, a slight altering of the facts in any of these cases can lead to situations in which both tests lead to liability. ${ }^{50}$ And an equally slight

49 Of course, in a Coasian world of perfect information and zero transaction costs, the choice of rule would be irrelevant. The parties would negotiate for an optimal allocation of safety costs. See R. H. Coase, The Problem of Social Cost, 3 J. Law \& Econ. 1 (1960).

so In our first hypothetical case, for example, assume not only that Marshall's drug company is in the best position to assess risks and benefits but also that the side effect, ex post, is sufficiently dire that the product cannot be viewed as worth using despite its undoubted advantages. 
altering of the facts can lead to situations in which neither test leads to "injurer' liability. ${ }^{51}$

The issue is an empirical one, and relatively small fact differences can lead to diametrically opposed results. This is especially true because the factors that both tests weigh by no means always point in the same direction. There are almost always choices between risks and benefits on both the injurer's and the victim's side. The user-victim is in a better position to assess some risks and some benefits, while the producer-injurer is in a better position to assess others. The question under the strict liability test is always which choices are more important and which party is best placed to make and to act on these. Similarly, the question of whether a product that may do some serious harm has advantages worth its risks is never easy, whether it is answered by a social decision maker only on the basis of the foresight that should have been available to the parties as in test 1 or with the benefit of hindsight as in the ex post test (3).

That the issue of which test leads to which result is essentially an empirical one, and that the tests can reach different results, indicates that each nonfault test looks at different relevant facts. At least, the tests emphasize different facts, and judicial language in use today seems to draw attention to these different concerns. When courts speak of the reasonableness of the product rather than of the producer, ${ }^{52}$ they are emphasizing factors that are primarily relevant to the ex post Learned Hand test. When, instead, courts speak of user expectations, ${ }^{53}$ latent versus patent defects, ${ }^{54}$ usual and unusual (as against negligent) uses of a product, ${ }^{55}$ and assumption of risk, ${ }^{56}$ they are emphasizing factors that are relevant to the strict liability tests.

Warning and its adequacy are relevant to both nonfault tests but in somewhat different ways. For the ex post Learned Hand test, adequate

\footnotetext{
51 In the second hypothetical case, assume that a previously unknown side effect does develop. But though significant, it is not so dire that a social decision maker can say that it outweighs the advantages for some people of carrying on their important work.

52 See note 4 supra.

53 See note 2 supra.

54 For example, Edwards v. Springfield Coca-Cola Bottling Co., 495 S.W.2d 489, 493 (Mo. App. 1973); Lockett v. Gen. Elec. Co., 376 F. Supp. 1201, 1212 (D.C. Pa. 1974); Vincer v. Esther Williams All-Aluminum Swimming Pool Co., 69 Wis. 2d 326, 352, 230 N.W.2d 794, 798 (1975).

55 For example, Hentschel v. Baby Bathinette Corp., 215 F.2d 102 (2d Cir. 1954), cert denied, 349 U.S. 923 (magnesium struts in baby bathinette exhibited highly incendiary properties when exposed to temperatures in excess of 1,000 degrees Fahrenheit); McCready v. United Iron \& Steel Co., 272 F.2d 700 (10th Cir. 1959) (cross-members of window casement collapsed when used as a ladder).

56 See note 41 supra.
} 
warning is a way in which a dangerous product can become worth its risk ${ }^{57}$ because a good warning will exclude some uses and some users and hence some risks. Like a good guard on a rotary mower, it may reduce the risks sufficiently so that the product seems to be worth its dangers. ${ }^{58}$ Or it may not. Even with a guard or a warning, on the basis of what we know now, the product may be deemed too dangerous and give rise to ex post liability. It may turn out that people in the risky category do not heed the warning and continue to use the product or it may turn out that the guard still allows too many stones to be thrown. Though the producer reasonably assumed that these safeguards would be enough, in retrospect the product may still be deemed unreasonable. A fortiori, absence of any warning ex ante may under the ex post test mean that the product without a warning was "unreasonable."

For the strict liability test, a warning becomes a way of trying to put the user in the best position to decide whether the benefits of the product outweigh its risks. ${ }^{59}$ Once again, the warning may work or may fail. The producer's choices-between making (or initiating the research necessary to enable the making of) a safer product and the accidents such a safer product will avoid-may be more significant than the user's choice between the existing product and a substitute..$^{60}$ If so, even a warning that is fully intelligible to the user would not suffice under the strict liability test. ${ }^{61}$ In contrast, even a weak warning may be enough if the user's

\footnotetext{
57 One set of circumstances in which a warning will be most valuable obtains when the product has certain irreducible risks, which are, however, far outweighed by the product's benefits-when it is used with caution. Restatement (Second) of Torts $\S 402 \mathrm{~A}$, comment $k$ (1965).

58 Indeed, warnings have occasionally been treated as just another design feature, blurring the distinction between failure to warn and product defect. For example, Carter v. Johns-Manville Sales Corp., 557 F. Supp. 1317, 1320 (E.D. Tex. 1983); W. Page Keeton, Products Liability -Inadequacy of Information, 48 Tex. L. Rev. 398, 403 (1970). Compare Wheeler \& Kress, supra note 46.

59 See generally Borel v. Fibreboard Paper Prods. Corp., 493 F.2d 1076, 1089 (5th Cir. 1973); Sills v. Massey-Ferguson, Inc., 296 F. Supp. 776 (N.D. Ind. 1969); Finn v. G. D. Searle \& Co., 35 Cal. 3d 691, 200 Cal. Rptr. 870, 677 P.2d 1147 (1984).

60 See, for example, Brochu v. Ortho Pharmaceutical Corp., 642 F.2d 652, 655 (Ist Cir. 1981 ) ("when an unreasonable danger could have been eliminated without excessive cost or loss of product efficiency, liability may attach even though . . . there was adequate warning," quoting Thibault v. Sears, Roebuck \& Co., 118 N.H. 802, 808, 395 A.2d 843, 847 (1978)); Uloth v. City Tank Corp., 384 N.E.2d 1188 (Mass. 1978); Borel v. Fibreboard Paper Prods. Corp., 493 F.2d 1076, 1104 (1973).

${ }^{61}$ Of course, an argument can be made that an intelligible warning is all that should be required: if consumers are well informed as to the potential hazards of a product, they can always negotiate with the manufacturer (whether directly or by "voting with their feet") to produce a safer product if the benefits of doing so outweigh the costs. But in the presence of
} 
knowledge of the benefits or the risks to him or her of using this product as against its substitutes is far superior to the producer's.

A court may, of course, decide to impose liability on the injurer if either of the two tests is failed. Thus one reading of the two-legged test of Barker v. Lull $^{62}$ is that producers are liable either if they are in the best position to evaluate the risks and benefits of a product or if, no matter who is best suited to do this, a court or jury determines on the basis of hindsight that the risks imposed by a product are not worth the benefits the product yields. The same has always been true with respect to nuisance. Liability may be placed on the polluter if on a (retrospective) balancing of the interests (made by court or jury) the harm of the stench outweighs its benefits. ${ }^{63}$ But it may also be placed on the polluter because that party can best decide whether additional preventive measures are worth taking, and this may be done even though the court or jury cannot, itself, say that the pollution ought (in retrospect) to have been avoided. ${ }^{64}$

information and decision-making costs, it may be evident that manufacturers are better positioned to make risk/benefit evaluations than are consumers and that strict liability is a better mechanism for internalizing costs than are market transactions between the parties. See generally Coase, supra note 49; and Guido Calabresi, Transaction Costs, Resource Allocation and Liability Rules-Comment, 11 J. Law \& Econ. 67 (1968).

62 See note 23 supra.

63 See, for example, Robie v. Lillis, 112 N.H. 493, 496, 299 A.2d 155, 159 (1972) (" [t] proper consideration of all the relevant circumstances involves a balancing of the gravity of the harm to the plaintiff against the utility of the defendant's conduct, both to himself and to the community'); Pendergrast v. Aiken, 293 N.C. 201, 236 S.E.2d 787 (1977). Although courts do not often expressly say they are using hindsight in these cases, the formulation of the nuisance test evinces a willingness to focus on the effects of a nuisance rather than on the (ex ante) reasonableness of the defendant's behavior: "[T] the plaintiff's use of his property can be unreasonable even when the defendant's conduct is reasonable." Prosser \& Keeton on the Law of Torts, supra note 30, § 88, at 629.

64 For example, Boomer v. Atlantic Cement Co., 26 N.Y.2d 219, 226, 309 N.Y.S.2d 312, 317,257 N.E.2d 870,873 (1970) ("'[i]t seems reasonable to think that the risk of being required to pay permanent damages to injured property owners by cement plant owners would itself be a reasonable effective spur to research for improved techniques to minimize nuisance'); Richards v. Village of Edinburg, 97 Ill. App. 2d 36, 239 N.E.2d 479 (1968); Blue v. Charles F. Hayes \& Assoc., Inc., 215 So. 2d 426 (Miss. 1968); see generally William L. Prosser, Nuisance without Fault, 20 Tex. L. Rev. 399 (1942); Restatement (Second) of Torts $\S 822$ (1979). Many of the cases involving an ex post weighing of costs and benefits result in a grant of injunctive relief. The equitable nature of the remedy leads to an ex post "balancing of the equities" by the court. See Prosser \& Keeton on the Law of Torts, supra note 30, $\S$ $88 \mathrm{~A}$, at 631 . Cases in which an injunction is denied but damages are granted, for example, Boomer, 26 N.Y.2d 219, serve as the strict liability test would, to internalize the costs of the activity so that the actor can judge the cost effectiveness of continuing it: see generally Guido Calabresi \& A. Douglas Melamed, Property Rules, Liability Rules, and Inalienability: One View of the Cathedral, 85 Harv. L. Rev. 1089 (1972). 


\section{The Choice between the Nonfault Tests}

When should a court prefer a strict liability test, and when should it prefer the ex post Learned Hand test? The question is posed most sharply when the strict liability test is considered in its ex post form. Except for the added fact of hindsight, the grounds for choice remain much as they were when Calabresi originally treated the issue of when negligence tests and when strict liability tests are likely to work better. ${ }^{65}$ Very briefly, two factors are crucial: $(a)$ the level of generality at which the decision is being made and $(b)$ the knowledge of risks and benefits available to the decision maker. If the choice is made at a broad level of generality, Learned Hand tests will rarely be used. Either liability will be placed on the category (injurers or victims) that can best make cost-benefit assessments or if the cost-benefit assessment can be made collectively at the broad level of generality, direct regulations-whether accompanied by civil penalties or criminal sanctions-will be used instead of torts. (A product will be banned, driving by people below a certain age will be prohibited, or an activity-drinking-will be barred to those below a certain age.)

If instead the choice is made on a case-by-case basis or at a low level of generality, then the two Learned Hand tests (1 and 3) and the strict liability tests ( 2 and 4 ) all become possibilities. In this situation, when the relative size of accident and safety costs is reasonably clear, collective decisions based on direct comparisons of these are apt to prevail, and Learned Hand-type tests are apt to be used. When, instead, such comparisons are hard to make, social decisions are likely to be more agnostic and to be based not on the result desired but on an assessment of which party is most likely to bring about the correct result if given the incentives to make that choice. The strict liability test will then predominate.

Thus if the court is comfortable with its own (and a jury's) capacity to decide what risks are worth taking-at least when all the retrospective data are available - it is apt to impose liability regardless of which party can assess risks and benefits better. It will insist on its own prerogative, as representative of the state, to decide what is and what is not worth doing. ${ }^{66}$ This will be true especially when important choices are available to both parties so that which party is in a better position to decide between safety and risk and to act on that choice is quite uncertain. Conversely, the more difficult it is to tell whether a product is worth having in

65 Calabresi \& Hirschoff, supra note 7. See also Calabresi, supra note 13, at 255-59.

66 Since the allocation of damages in a particular case is not the end of the more general issue, an error in the court's cost-benefit analysis may be corrected later. 
its current state, the more a court will seek to determine which of the parties can make that decision most intelligently. It will try to determine where incentives are best placed and assign accident costs accordingly.

It follows that in evaluating and criticizing judicial decisions in each area of torts, we must consider whether the courts have insisted on their own capacity to assess risks and benefits when, in fact, they would have done better had they looked to the parties' relative capacity to choose. But we should be equally critical if courts have been too hesitant and have sought the best decision maker when in fact the decision should clearly be for or against the product. ${ }^{67}$

We should also ask that, though both approaches have their merits, courts be considerably more clear as to which they are using. This is not to say that they may not mix them-and perhaps introduce the ex ante Learned Hand test as well. It is only to ask that when they mix tests, and even when they do not, they tell us and the parties what they are doing so that victims and injurers both will know better what is asked of them.

It has always been reasonably clear that in areas such as workers' compensation, ${ }^{68}$ ultrahazardous activity, ${ }^{69}$ and first-party automobile plans,${ }^{70}$ the dominant test has been the strict liability one (whether it resulted in injurer loss bearing, as in the first two of these, or in victim loss bearing, as in the last). Because those decisions were made at a broad level of generality, the question of whether the risk was, ex post, worth taking rarely seemed to be asked. Placing losses on the category best suited to evaluate risks and benefits seemed the better approach.

When, instead, the liability decision is made at a low level of generality, or case by case, the two approaches are both available. Two sets of judicial formulas vie with each other for dominance. First, there is the set

\footnotetext{
67 In doing this, however, we must also consider, as Epstein has suggested, whether the object of products liability law (say) should predominantly be to increase the knowledge of the parties so that they can make risk-benefit assessments best, or whether it should also be to set standards of safety to which even those who might knowingly choose greater risks for greater benefits will be encouraged to adhere. Richard A. Epstein, Commentary, 58 N.Y.U. L. Rev. 930 (1983) (commenting on Victor Schwartz, The Post-sale Duty to Warn: Two Unfortunate Forks in the Road to a Reasonable Doctrine, 58 N.Y.U. L. Rev. 892 (1983)). We are not here speaking only of consumers' risk taking, for at the theoretical level the issue is, of course, symmetrical; and one can equally argue that producers should be given the right to gamble on products that will lead to disastrous losses if they turn out badly, but will lead to dramatic profits if they turn out well.

${ }^{68}$ See note 15 supra.

69 Id.

70 See generally Roger C. Henderson, No-Fault Plans for Automobile Accidents, 56 Or. L. Rev. 287 (1977); compare Guido Calabresi, The New York Plan: A Free Choice Modification, 71 Colum. L. Rev. 267 (1971).
} 
that includes "assumption of risk,"71 "no proximate cause,",72 "the injurer is held to know the nature of his or her beast," "73 "the product was used in a usual (or unusual) way," "74 "the warning was not sufficiently adequate to inform the user of the risks," 75 and many others. The competing cluster includes "is the product sufficiently useful so that despite its now apparent dangers it is not defective", 76 "balancing the equities, and knowing what we now know, we must decide whether the pollution is a nuisance or whether it is sufficiently socially useful so that the smell must be borne by the neighboring landowners" ${ }^{77}$ and so on. There is nothing intrinsically wrong with the struggle, but it would be helpful if we were told, clearly, which approach was being followed or even that one party must pass both sets of tests or be liable.

\section{Reasons for the Ascendancy of the No-Fault Tests}

The question remains, however, why should our legal system have moved away from the traditional Learned Hand test (1a)? Why should it have gone to the no-fault tests $(2,3$, and 4$)$, rather than, if it wished to favor victims, simply to a reverse Learned Hand test ( $1 \mathrm{~b})$, perhaps even with burdens of proof placed on injurers? The question has two parts, as suggested earlier. First, why might one prefer a test that asks who can decide-a strict liability test-rather than a test that asks what costbenefit analysis ought to have prevailed when the decisions were made? Second, what use is it to impose liability for past actions on the basis of data that are available only with hindsight, as in the ex post Learned Hand test or the ex post version of the strict liability test, rather than applying such data only prospectively? How can this help even future decisions when actions can only be based on what is, at the time, known or knowable?

71 See note 16 supra.

72 See Calabresi, supra note 32, at 81-83.

${ }^{73}$ For example, Behrens v. Bertram Mills Circus Ltd. [1957] 2 Q.B. 13 (stampeding elephant causes injury to circus midgets); Marshall v. Ranne, 511 S.W.2d 255 (1974) (plaintiff trapped in his house by neighbor's boar).

${ }^{74}$ See Singer v. Walker, 331 N.Y.S.2d 823 (1972), aff.'d 32 N.Y.2d 786, 345 N.Y.S.2d 542, 298 N.E.2d 681 (1973); McDevitt v. Standard Oil Co., 391 F.2d 364 (5th Cir. 1968).

75 An extreme example of this extensive genre of inadequate warning cases is Rawlings Sporting Goods Co. v. Daniels 619 S.W.2d 435 (Tex. Civ. App. 1981) (manufacturer held negligent for failure to warn that football helmet would not protect against blood clot resulting from violent head contact).

${ }^{76}$ For example, Beshada v. Johns-Manville Prods. Corp., 90 N.J. 191, 447 A.2d 539 (1982); Barker v. Lull Eng'g Co., 20 Cal. 3d 413, 143 Cal. Rptr. 225, 573 P.2d 443 (1978) (one of two tests); Turner v. Gen. Motors Corp., 584 S.W.2d 844 (Tex. 1979).

77 For example, Robie v. Lillis, 112 N.H. 492, 299 A.2d 155 (1972). See note 63 supra. 
We have already treated the first question briefly in the last section, and Calabresi has discussed it at length elsewhere. ${ }^{78}$ Thus we need to spend little more time on why-even with hindsight-decision makers may feel uncertain as to how the cost-benefit balance should be struck and may prefer, therefore, to concentrate on finding the party best suited to strike the balance. We should note, however, that, to the extent that tort law has moved toward making more decisions at a highly generalized, abstract level and fewer at a particularized, case-by-case level, the decline of the Learned Hand test (1) follows almost automatically. At a highly generalized level, the equivalent of the Learned Hand test is prohibition of behavior and of products deemed not to be worthwhile. Once the decision is made, as a general matter, that certain risks are not worth taking, society will normally not simply impose damages but will prohibit the "unreasonable" behavior or product as well.

Because direct regulation or criminal law, each with its associated penalties and sanctions, is involved, however, such decisions will be prospective only. Since, moreover, use of such prohibitions substantially deprives the would-be producer, user, or actor of the chance to secondguess the social decision (as can be done when tort suits are brought), society is likely to be more hesitant to strike such a balance than it is to strike a Learned Hand balance. An error in the cost-benefit analysis made at a generalized level is much more apt to endure if it results in regulatory or criminal sanctions than if it results only in civil damages. For this reason, if sufficient doubt exists, the decision at the generalized level will be for a strict liability test instead. Rather than deciding what is worth doing (and enforcing that determination with regulatory or criminal penalties), the decision will be to identify the category best placed to decide what is worth doing and-by imposing strict liability-induce that party to decide well. ${ }^{79}$

\footnotetext{
78 Calabresi \& Hirschoff, supra note 7.

${ }^{79}$ Indeed, the existence of the criminal regulation alternative may go a long way toward explaining why in the nineteenth century the civil Learned Hand test was so frequently used. If one merely compares strict liability tests and Learned Hand tests, a laissez-faire era would be expected to prefer the less interventionistic strict liability tests, based as they are on who can decide best, over those that require agents of the state to decide what is worthwhile. This to some extent occurred, as Robert Rabin has demonstrated, in doctrines like assumption of risk and proximate cause. Robert L. Rabin, The Historical Development of the Fault Principle: A Reinterpretation, 15 Ga. L. Rev. 925 (1981). But frequently what was at issue was not strict liability versus negligence but case-by-case decisions versus generalized rules and, hence, negligence versus regulation. It is not surprising that a laissezfaire era would prefer, as it did, case-by-case decisions, resulting in civil damages, which allowed actors to second-guess the social decision makers, to generalized criminal sanctions and regulations.
} 
The coming of the activist state has made us much more willing to decide things at broad general levels and to enforce these decisions through regulations. Ironically, however, it has also led us to use the relatively libertarian strict liability approach more frequently than we did in the nineteenth century for those situations in which, at the now-desired generalized level of decision making, a risk-benefit assessment seems too uncertain to be made with the finality of collective sanction. ${ }^{80}$

The second question to be taken up in this section requires more treatment. Why, when a decision on liability is being made on a case-by-case basis, should courts and juries employ hindsight? In approaching this issue, we shall focus on the use of hindsight in making a collective assessment of risks and benefits instead of just a determination of who is the best decision maker to burden. This seems the harder case to make for the use of hindsight: it is reasonably clear that if society wants only to burden the best decision maker, with an eye to affecting future actions, then it wants to use the best information currently available in making that determination. Why, however, when a collective decision is made about the appropriateness of the actions themselves, should we think that liability for past actions, based on what has only come to light since the actors acted, would be a better guide to future behavior than liability based on what the actors knew or should have known? Why, in other words, should one use the ex post Learned Hand test (3) instead of the classic Learned Hand test (or its mirror image) (1)?

First, notice once again that this choice is neither new nor based only on distributional concerns, though it is affected by them. In nineteenthcentury nuisance law, the balancing of equities that took place, ex post and regardless of injurer negligence, was frequently (and in as muddled a fashion as we see sometimes in product liability today) a use of the ex post Learned Hand test (3). ${ }^{81}$ Then, as now, some distributional factors were involved (landowner victims may have been favored, other things being equal). Then, as now, liability was often placed on the basis of who could

80 That the particular strict liability tests used have been ones that favor victims, as against the nineteenth-century proinjurer ones, reflects other significant changes in social attitudes; but these, though fundamental, are to the side of the point of this paper. Had distributional attitudes remained unchanged while laissez-faire declined, we would likely have still seen a move to generalized rules leading to regulation in some cases and strict liability in others. But victims would have been the parties burdened, by both regulations and strict liability, far more frequently than is the case today.

81 See, for example, Rindge v. Sargent, 64 N.H. 294, 294-95, 9 A. 723, 724 (1887) ("[a] use is reasonable which does not unreasonably prejudice the rights of others. In determining the question of reasonableness, the effect of the use upon the interests of both parties-the benefits derived from it by one, the injury caused by it to the other-and all the circumstances affecting either of them, are to be considered'). 
decide best, ${ }^{82}$ and these decisions were intermingled with ex post Learned Hand decisions. ${ }^{83}$ But the fact remains that, even then, a major area of tort law seemed at times to rely on the notion that liability for past actions, based on hindsight, might lead to better control of future behavior than would prospective liability.

Second, notice that the same kind of skepticism that is directed at the use of hindsight -in terms of its effect on deterrence-can be raised about the use of an objective definition of reasonableness in traditional negligence and against the employment of a strict liability test. Yet, in the first of these areas, the argument was rejected at the very beginning of modern tort law $;{ }^{84}$ and in the second, it has been ignored as frequently as it has been made during the last hundred years. ${ }^{85}$ The logic of the argument is the same in each case: if people cannot do any better, then assigning the resulting losses to them cannot lead to greater safety.

The logic of the argument is indeed persuasive, and the skepticism to which it gives rise is justified, but only in a world of perfect knowledge and frictionless performance by the relevant actors. This would require that all actors-including potential injurers, potential victims, courts, and juries-be perfectly informed about potential risks, the precautions that can be taken to avert them (including any randomness in the effectiveness of such measures), and the steps that can be taken to acquire new information about risk creation and precaution taking; that neither potential injurers and victims nor the setters and appliers of standards-courts and juries-ever err in their decisions; and that all actors know that they are all so omniscient and error free.$^{86}$ If the traditional negligence test (1) were

${ }^{82}$ See note 64 supra.

${ }^{83}$ See note 63 supra.

${ }^{84}$ See, for example, Vaughan v. Menlove, 3 Bing. N.C. 468, 132 Eng. Rep. 490 (C.P. 1837) (per Tindal, C.J.) ("[i]nstead, therefore, of saying that the liability for the negligence should be coextensive with the judgment of each individual, which would be as variable as the length of the foot of each individual, we ought rather to adhere to the rule which requires in all cases a regard to caution such as a man of ordinary prudence would observe"); Worthington v. Mencer, 96 Ala. 310, 11 So. 72 (1892).

${ }^{85}$ See, for example, O. W. Holmes, Jr., The Common Law 161 (1881) (" "It]he theory of tort may be summed up very simply. At the two extremes of the law are rules determined by policy without reference of any kind of morality. Certain harms a man may inflict even wickedly; for certain others, he must answer, although his conduct has been prudent and beneficial to the community'). Compare Richard A. Epstein, Modern Products Liability Law (1980) (any actor who undertakes a risky activity harming strangers should be liable for the harm he causes regardless of whether he intended the harm or whether the activity would pass a social cost/benefit test).

${ }^{86}$ Peter Diamond provided the first rigorous exegesis of the role of uncertainty in his formalization of Calabresi's theories. Peter A. Diamond, Single Activity Accidents, $3 \mathrm{~J}$. Legal Stud. 107, 123-40 (1974). Diamond recognized that there is a stochastic element to the 
in effect in such an environment, there should be no cases in which a rational person would ever be found liable: ${ }^{87}$ the test only imposes liability when the ex ante avoidance costs are less than the ex ante risk-discounted accident costs. Therefore, any rational, calculating actor should opt for safety in all those cases in which, if an accident were to occur, he or she would be held liable. It is, by definition, cheaper and hence more advantageous for him or her to do this. Yet fault and liability are frequently found under the classic Learned Hand test (1) and were even years ago when one could scarcely doubt its purity.

The world of perfect knowledge and frictionless performance is, indeed, far different from that in which we live and in which liability rules are designed to operate. Consider just two examples of possible decisionmaking error. First, even if parties are capable of responding correctly to the threat of liability, they may, for psychological reasons, systematically overestimate safety costs or underestimate accident risks ${ }^{88}$ and may act in ways that are negligent. Second, and equally important, if parties believe that the social decision maker systematically underestimates the riskdiscounted accident costs or overestimates the safety costs, known or knowable at the time of action, they will find it worth their while to take risks that, from society's point of view, are not worth taking. ${ }^{89}$ If the social decision maker is actually so "biased" - that is, if the actors' beliefs are well founded-parties who take undesirable risks will bear lower costs than if they exercised their best judgment.

provision of 'care and modeled the effect of stochastic measurement of care by the courts. See also Jerry Green, On the Optimal Structure of Liability Laws. 7 Bell J. Econ. 553 (1976). Steven Shavell has noted that the effect of uncertainty is to introduce significant elements of strict liability into the fault system because, in some cases, injurers who exercise, or attempt to exercise, due care will still be held liable. Shavell, supra note 33, at 489. Mark Grady has recently argued that, in the face of uncertainty, injurers will tend systematically to over- or underprovide care, depending on the causation rule in effect. Mark F. Grady, A New Positive Economic Theory of Negligence, 92 Yale L. J. 799 (1983).

87 See also William M. Landes \& Richard A. Posner, The Positive Economic Theory of Tort Law, 15 Ga. L. Rev. 851, 879-80 (1981).

${ }^{88}$ For example, psychological studies have demonstrated that individuals tend to underestimate the likelihood of events that are difficult to imagine or that lie outside the range of ordinary experience (for example, death or serious disfigurement). See generally Amos Tversky \& Daniel Kahneman, Judgment under Uncertainty: Heuristics and Biases, 185 Science 1124 (1974); Paul Slovic, Baruch Fischhoff \& Sarah Lichtenstein, Cognitive Processes and Societal Risk Taking, in Cognition and Social Behavior 165 (John S. Carroll \& John W. Payne eds. 1976); Paul Slovic, The Psychology of Protective Behavior, 10 J. Safety Research 58 (1978); Robin M. Hogarth, Cognitive Processes and the Assessment of Subjective Probability Distributions, 70 J. Am. Statistical A. 271 (1975).

89 See generally Steven Shavell, Liability for Harm versus Regulation of Safety, $13 \mathrm{~J}$. Legal Stud. 357, 359 (1984) (disparities in knowledge between litigants and the state may lead to misallocations). 
Once the possibility of error in striking a risk-benefit balance is admitted, liability systems that seem bound to add nothing in a fullinformation, error-free world may well make a significant difference. Whether the difference is "good" or "bad" depends on the nature and direction of the dominant errors. It is an empirical question on which precise data may be difficult to obtain but about which good guesses in the absence of hard data are essential.

As argued earlier, there is no reason, in theory, why, relative to the classic Learned Hand test (1), the ex post Learned Hand test (3) necessarily imposes liability more frequently on the party to whom the test is applied. If, however, as a practical matter, the ex post test does result in liability far more often than would the ex ante test, this suggests that the social decision makers or the private parties or both groups systematically tend to overestimate ex ante avoidance costs or underestimate ex ante risks. ${ }^{90}$ If that is in fact the case, a good argument exists for employing one of the nonfault tests $(2,3$, or 4$)$ : these tests serve to correct the behavioral biases otherwise generated by private or social actors. The point can be sharpened by considering possible sources of systemic problems.

As a first example, if overestimation of ex ante avoidance costs and underestimation of ex ante risks is primarily due to the collective decision maker, a good argument can be made for the strict liability test (2). Indeed, the same argument can be made for that test if the social decision maker errs in the opposite direction. Either way, the private party best suited to decide between costs and benefits is likely to do better than the court, jury, or administrative agency, which is, by hypothesis, systematically in error. The preference for the strict liability test would cease to obtain, of course, if the social decision maker were wrong as often when it sought to identify the party best placed to decide. But at the moment that quite real possibility does not concern us, as we are attempting not to establish the specific cases in which each test works best but simply to explain why each may be desirable in some situations.

Second, if instead the overestimates of avoidance costs and the underestimates of accident probabilities or costs are primarily, though still systematically, made by the private parties, a strict liability test ( 2 or 4$)$ is not apt to help much. The same errors will continue to be made. In such situations the ex ante or the ex post Learned Hand test is apt to be more desirable, for then the cost-benefit analysis will not be made by the, ex hypothesi, erring parties but rather by the social decision maker. That

90 There may, of course, be other-distributional-reasons why this result may seem to be reached. 
decision maker's independent judgment and statement that the accident ought to have been avoided may be more likely to lead the parties, in the future, to overcome their original, assumed antisafety bias. In this situation, moreover, the ex post Learned Hand test also has an advantage over the ex ante one. By assigning liability on the basis of the most current data available, the ex post test makes clear to future actors-who, by assumption, err in the underprotection direction-what society now believes it knows and therefore what ought to be avoided in the future.

Such examples can be multiplied. Thus if the parties' errors were not in the ex ante risk-benefit analysis itself but in their judgment of how the collective decision maker would do such an analysis, the strict liability test (2) would seem to be more likely to avoid errors than the ex post Learned Hand test. At least this would be so unless the parties believed that the collective decision makers would decide correctly if but only if they based their decisions on ex post data. For then, once again, the ex post Learned Hand test might well be superior.

It is important to note that the use of an ex post test engenders uncertainty of its own and brings with it some attendant unfavorable effects on actors' behavior. If the actor is aware that his or her behavior today will be judged against the standard of knowledge at some future time, the actor will have more difficulty gauging the stringency of the standard than if only what is known or knowable today were to matter. As several recent articles have demonstrated, even if all uncertainty about a legal standard is unbiased-centered on the socially optimal level of care-and actors are risk neutral, the presence of the uncertainty alone can induce the affected parties to spend too much or too little on safety. ${ }^{91}$ Hence, even if the standard of care based on hindsight at some future time were in fact identical to the standard of care required under a test using only

\footnotetext{
91 See John E. Calfee \& Richard Craswell, Some Effects of Uncertainty on Compliance with Legal Standards, 70 Va. L. Rev. 965 (1984). Grady, supra note 86; Mark F. Grady, Proximate Cause and the Law of Negligence, 69 Iowa L. Rev. 363 (1984). Note that a' rough correction for the bias of the parties toward underprovision of safety could be achieved by other than an ex post test and with far lower administrative costs: since, by hypothesis, the defendant was acting in good faith given the information available ex ante, a judgment of liability based on facts or circumstances uncovered ex post is a stochastic event. If knowledge that such a "wild card" may be dealt to economic actors moves them toward fuller provision of safety, the same result could be obtained through a more overtly random mechanism, such as imposing punitive damages in every tenth case. Beyond the fact that such overt randomness would be repugnant to due process and other important justice norms, using an ex post rule instead allows participants in the lottery to purchase better information and to benefit from what they learn. By conducting more extensive testing, a manufacturer may be able at least partially to predict whether it will be considered liable from an ex post viewpoint-simply by pushing the state of the art forward to the point at which evaluations made ex ante are consistent with those made ex post. See Section $X$ infra.
} 
current knowledge, the uncertainty generated by an ex post test could induce undesirable behavior by private actors. One might well imagine that, because taking more care will reduce the probability of being held liable, the uncertainty associated with use of an ex post rule would be more likely to lead to too much rather than too little being spent on safety; but that is only a guess.

Perhaps most important, the strict liability tests ( 2 and 4 ) involve their own possibilities of error. First, the collective decision maker may err in choosing the parties best suited to strike the cost-benefit balance. Second, if this choice is made on a case-by-case basis, the parties may erroneously believe that the collective decision maker will err in individual cases. If the likelihood of error, whether real or perceived by the parties, is lower when the collective decision maker decides (ex post) what is worthwhile rather than deciding who is best placed to decide, then once again the ex post Learned Hand test (3) may prove superior.

This fact, together with our earlier comments about collectively imposed sanctions-whether regulatory or criminal-may help explain why courts might use the ex post test in nuisance and product liability law while the strict liability test dominates in workers' compensation, ultrahazardous (or abnormally dangerous) activity, and first-party auto nofault law. When strict liability is imposed on a case-by-case basis, two kinds of errors are possible: $(a)$ an error by the social decision maker in selecting who can decide best and $(b)$ an error by the parties in anticipating whom the decision maker will choose as best placed to decide. It is not surprising, therefore, that in those areas of torts, like nuisance and products liability, in which case-by-case decisions predominate, the ex post Learned Hand test might be an attractive no-fault instrument of choice. On the other hand, strict liability is much more likely to be used when generalized decisions about who can decide best between accident and safety costs seem feasible, for then no perception error on the part of the parties is possible.

Appropriate placement of burdens of proof can, of course, reduce the chance of error in applications of the various tests. It cannot, however, guarantee that they will not occur. For that reason, the allocation of burdens of production of evidence and risks of nonpersuasion becomes a way, like the choice of tests, of reducing the chance of making those errors that are considered most damaging. ${ }^{92}$ The allocation is not a substitute for choosing the test that minimizes the social losses due to errors but

\footnotetext{
92 "Most damaging," of course, means most damaging for distributional and justice reasons as well as for deterrence reasons. See generally Calabresi, supra note 13, at 198-235.
} 
rather a not so fine fine-tuning device to be used in conjunction with the choice of tests.

This analysis suggests, moreover, that, as to both burden of proof and choice of test, the same rule need not be used for all parties. Just as different areas of tort law may be best served by different tests, social losses may be minimized if liability for one party is based on one test with one burden of proof while liability for the other party is made to depend on another test with perhaps another burden of proof. It also follows from our analysis that the system may place liability on one or another party if any one of several tests is failed.

The overall choice depends on how likely and how serious the errors are that the parties will make under each test and how likely and how serious the errors are that the social decision maker will make regarding the different parties under different tests: which combination of tests is more effective, in practice, in reducing the errors that trouble us most ? $^{93}$ Thus, for example, it is by no means necessarily absurd (though we take no stand pro or con in this paper) to have a liability system that holds producers liable under an ex post Learned Hand test unless it can be demonstrated that users either were best placed to decide between risks and accidents (assumed the risk) or behaved in a way that ex ante was unreasonably risky (were contributorily negligent). Nor is it necessarily absurd to have burdens of proof for some of these issues fall on one party while others fall on the other party.

\section{The Choice among Tests-Incentives to Acquire NeW INFORMATION}

Although differences in the social costs of errors of the no-fault tests constitute an important reason why one of them $(2,3$, or 4$)$ may be superior (or inferior) to ex ante negligence (1) and to the others, these costs do not tell the complete story. Here we will discuss briefly just one other factor, namely, how the tests affect incentives to find (or to hide) relevant facts and to add to what we know about potential risks and about how to avoid-or at least to diminish-them and which approach is more likely to bring significant data to light. We can, in this paper, only suggest the relevance of this complicated issue to the choice of test.

Consider first the effects of ex ante versus ex post tests on information gathering at the time actions are taken, that is, their effects on reduction of the ex ante level of uncertainty. An actor who knows that his or her

\footnotetext{
93 Note, however, that there are positive costs (both administrative and morale costs) to proliferating decision rules. See Section XI infra.
} 
behavior will be subject to an ex post test will have more of an incentive to anticipate future developments. Hence, he or she will arguably see greater payoff to learning more now, as opposed to finding out only later with perhaps quite dire financial consequences, than will someone whose conduct is judged only on the basis of what is known or knowable at the time of the act. It is possible, of course, that the added motivation will lead to more information gathering than is optimal, but it is equally plausible that the ex ante test leads to too little research from a social point of view. ${ }^{94}$

Turn now to the postaccident incentives to acquire new information. An ex ante test, it can be argued, provides no incentive for the party who will win only if the other party fails the test to discover and make known facts not reasonably available at the time the relevant behavior took place. Suppose Taney can recover from Marshall only if Marshall knew or should have known that the risks of a certain product outweighed its benefits. Then Taney will have little interest in spending time or money digging out previously unknown facts that demonstrate that hereafter sale or manufacture of the product is unreasonably dangerous. He would lose anyway. If, instead, Marshall is subject to an ex post test, Taney has everything to gain by digging out the same facts. Of course, how much time, effort, and resources Taney will actually devote to unearthing such new information will depend on who Taney is and what the case is. For example, it seems plausible that a single consumer in a products liability suit against a pharmaceutical company is much less likely to put forth the effort than is a labor union in workplace safety litigation against a set of manufacturers. Since availability of these new facts serves to promote better safety in the future, the ex post approach, which is more likely to produce the facts, is, other things being equal, superior.

The same is true, of course, as to facts that would demonstrate, ex post, that what seemed to be an unreasonable risk ex ante is in fact worthwhile. Thus under an ex post test Marshall would have incentives-after the accident-to find previously unavailable data tending to demonstrate that "safety" was riskier or more costly than it might have seemed, that the benefits of the action were greater than they had been believed to be, or that accident risks were smaller than would have been predictable. Marshall would have much less interest in finding such facts under the traditional Learned Hand test (1). For under a strict ex ante test, these facts

\footnotetext{
94 For an elegant analysis of how one might decide the optimal efforts to devote to information gathering in the face of remote risks, see Alan Schwartz, Products Liability, Corporate Structure, and Bankruptcy: Toxic Substances and the Remote Risk Relationship, in this issue.
} 
would not serve to excuse Marshall from liability if at the time he acted his behavior was unreasonable. ${ }^{95}$

One should not overstate the point, however. Even a strict ex ante test creates some incentives for developing facts after the accident. After all, if something is learned ex post, it does suggest that it might, reasonably, have been found ex ante and hence that not finding it before the accident itself violated the Learned Hand test (1). This means, to some extent anyway, that after the accident Taney may well seek new evidence damaging to Marshall in the hope that this will show that Marshall should have found this evidence himself earlier. Moreover, both Marshall and Taney will seek ex post data for another reason. They will both hope that such data will in practice influence the court or jury even if the rule stipulates that the decision maker should respond only to what was reasonably knowable ex ante. ${ }^{96}$

But one also should beware of overstating the incentives that exist for ex post fact finding under ex ante tests. Recall the traditional distinction in tort law between (by and large) inadmissible evidence that postaccident "safety measures" were undertaken and (usually) admissible evidence that preaccident "safety rules" were violated. ${ }^{97}$ There are clear differences between the two sets of issues, of course. But the point remains that courts and juries operating under ex ante tests are less likely to admit or welcome ex post data to show culpability and hence that the incentives to develop such data, however useful the data may be for future safety decisions, are quite limited. This may be especially harmful precisely because, immediately after an accident, the incentives to find such factsif they were deemed relevant to the liability decision-would be extremely great. After an accident, the finding of data bearing on safety and accident costs is for both Taney and Marshall much more than a matter of abstract or statistical relevance. Money turns on it, and immediately.

\footnotetext{
95 We do not mean that the classic Learned Hand test was in fact applied in so totally an ex ante fashion. Indeed we doubt that it was. See, for example, note 24 supra. But this just suggests that ex post approaches are neither so totally new nor manifestly odd.

96 See Grenada Steel Industries v. Alabama Oxygen Co., 695 F.2d 883, 888 (5th Cir. 1983) (" $[t]$ he jury's attention should be directed to whether the product was reasonably safe at the time it was manufactured. . . The introduction of evidence about subsequent changes in the product or its design threatens to confuse the jury by diverting its attention from whether the product was defective at the relevant time to what was done later"). This, of course, again suggests that, albeit surreptitiously, the traditional ex ante test admitted ex post data and hence serves once again somewhat to justify use of open ex post tests.

97 Compare Columbia \& Puget Sound Ry. Co. v. Hawthorne, 144 U.S. 202, 12 S. Ct. 591, 36 L. Ed. 405 (1892); Fed. R. Evid. 407 (evidence of remedial actions is incompetent) with Stevens v. Boston Elevated Ry. Co., 184 Mass. 476, 69 N.E. 338 (1903) (violation of internal safety rules probative of negligence).
} 
Since the ex post test makes such data clearly relevant, it would have a distinct advantage over the ex ante test.

Unfortunately, if the ex post test creates incentives to find facts, it may also create incentives to hide them. Under an ex ante test, Marshall has significant reasons to learn whether, hereafter, the product is knowably too dangerous and to take postaccident safety measures. And Taney would seem to have no reason to hide previously unexpected safety costs. Under an ex post test, however, Marshall may well seek to hide new and damaging evidence about the product's dangers or new information about possible accident-reducing measures, at least until earlier injury cases are settled..$^{98}$ (Taney may similarly seek to hide data suggesting that "safety" is riskier than was predictable.) Such a strategy on Marshall's part is, to be sure, very dangerous. It can give rise to avoidable future accidents for which Marshall would clearly be held liable, ${ }^{99}$ and it can lead to punitive damages in such accidents. Nevertheless, if the burden of possible liability for past accidents is great enough, and if it extends far enough back in time, Marshall may well decide that it is worthwhile to hide data tending to show that products sold in the past were in retrospect unreasonably risky - at least until the past cases are settled. ${ }^{100}$ One can imagine, for example, that, operating under an ex post test, a pharmaceutical company might be more reluctant to examine, as thoroughly as it could, reports of earlier severe side effects than it would were its liability only prospective.

As with the issue of possible errors, then, the question of relative

98 The court addressed this policy argument in Ault v. Int'l Harvester Co., 13 Cal. 3d 113 , 117 Cal. Rptr. 812, 528 P.2d 1148 (1975), a case admitting evidence of ex post remedial measures in a products liability case: "The contemporary corporate mass producer of goods, the normal products liability defendant, manufactures tens of thousands of units of goods; it is manifestly unrealistic to suggest that such a producer will forego making improvements in its product, and risk innumerable additional lawsuits and the attendant adverse effect upon its public image, simply because evidence of adoption of such improvement may be admitted." $13 \mathrm{Cal}$. 3d at 120, $528 \mathrm{P} .2 \mathrm{~d}$ at 1152 . Note, however, that this analysis presupposes a continuing marketing of the product. The incentives may be materially different when the product has been discontinued, and the question is whether the manufacturer should conduct further testing to uncover additional health effects from the product. On balance, the decision whether to undertake remedial actions will hinge on the effectiveness of the actions in reducing future liability relative to their prejudicial effect on current litigation.

99 See Noel v. United Aircraft Corp., 342 F.2d 232 (3d Cir. 1964) (continuing duty not only to warn of newly discovered hazard but also to research and develop adequate safety devices); Robert B. Patterson, Products Liability: The Manufacturer's Continuing Duty to Improve His Product or Warn of Defects after Sale, 62 Ill. B. J. 92 (1973).

100 Henderson provides an exhaustive catalog of the incentives for manufacturers to "freeze" their product designs to avoid a "confession by implication" that the original design was flawed. James A. Henderson, Jr., Product Liability and the Passage of Time: The Imprisonment of Corporate Rationality, 58 N.Y.U. L. Rev. 765 (1983). 
advantage in stimulating useful fact finding is an empirical one. Each kind of test-ex ante and ex post-may have significant merits; neither kind of test dominates the other.

The same is true if one compares the Learned Hand tests (1 and 3) with the ex ante strict liability test (2). Under that strict liability test, once it is decided that Marshall (say) is in the best position to strike and to act on the cost-benefit balance, there is little incentive for Taney to find new facts or for Marshall to hide them. The loss falls on Marshall in any case. ${ }^{101}$ Marshall, because he will be liable in the future anyway, has every reason to find and use new data about the safety cost/accident cost tradeoff, for with such information he can hereafter choose the cheaper alternative. Once the strict liability decision is made, the party freed from loss bearing becomes relatively passive with respect to future cost avoidance (and hence fact finding). The party held liable, instead, has every incentive to become very active in seeking data relevant to future accident and safety costs.

There are, again, limits to this analysis. The party on whom the loss does not fall may bear some noncompensable losses, and these may create some incentives. ${ }^{102}$ Also, too much passivity may ultimately result in a ruling that the previously immune party is ignoring relevant choices and hence trigger at least a partial reversal of the original strict liability determination. Finally, the strict liability decision may itself divide losses between the parties and thereby create limited fact-finding incentives for each. Still, the basic point remains that, by resting its decision on the relative fact-finding capacities of the parties, the strict liability test (2) tends to create excellent fact-finding incentives for some parties and poor ones for others. It also tends to diminish the dangers of fact hiding. ${ }^{103}$ Whether this combination of incentives is a good or a bad one, relative to the two Learned Hand tests ( 1 and 3), once again, is an empirical question.

\footnotetext{
101 There will still be an incentive for Taney to show that certain seemingly unrelated injuries were causally linked to Marshall's product, and Marshall may seek to deny or hide such a link. This may be relevant, for example, in pharmaceutical side-effects situations. But as to general facts relevant to the costs of safety and the costs of accidents, Taney has no special incentive to find data, nor Marshall to hide them.

102 A noncompensable loss is one for which money is generally regarded as an inadequate means of compensation, for example, permanent disabilities and pain and suffering. For discussions of the incentive effects of such losses, see Diamond, supra note 86, at 162-63; Calabresi, supra note 13 , at $65,214-225$.

${ }^{103}$ Again not fully: the choice of liability rule does not affect incentives to hide information on other elements of the case, namely, causal link.
} 


\section{Concluding Remarks}

Nothing in this paper should suggest that we favor one or another of the four liability tests discussed-and in particular the ex post Learned Hand test. Ultimately, the choice among the ex ante Learned Hand test (1), the strict liability tests ( 2 and 4 ), and the ex post Learned Hand test (3) is, as we have repeatedly said, profoundly empirical. While we have tried to suggest what kinds of facts matter and to suggest how different combinations of facts would support use of different tests, we have not ventured a guess as to how the facts actually emerge.

We have not done this, in part, because we do not know. Moreover, the pattern of facts in one setting, for example, workplace injuries, may well be (undoubtedly is) strikingly different from the pattern in another, for example, pharmaceuticals. But we also have not made these guesses because ours is only a partial analysis and for the most part puts to the side both distributional consequences and administrative costs. These last are quite likely to be extremely important in choosing a test and its level of generality. The significant administrative cost savings generated by abstract rules of great generality, as under strict liability regimes, are appealing, especially as the virtues of generalization can be combined with desirable distributional effects.

We are convinced of the need for a careful and close empirically based reexamination of our tort system that pays particular attention to important differences in the fact patterns that arise in different types of accident settings. The approach that is best to achieve just the primary accident cost reduction goal, to minimize the sum of accident and safety costs, in one area need not work best in other areas. But one should always remember that administrative costs multiply as one multiplies the number of different approaches used in different areas. For then parties will fightexpensively - to fit their situation into the category that seems most advantageous for them. Nevertheless, a tort system that disaggregates cases along structural lines, compartmentalizing recurring fact patterns meriting uniform treatment, and applies different rules to the resulting subsystems merits careful consideration. ${ }^{104}$

\footnotetext{
104 An alternative that also deserves thorough scrutiny, and that may well be preferable to such a "structuralist" approach, is an expansion of the strict liability approach toward a unitary system in which victims would receive damages from a general fund according to their injuries and in which both victim and injurer categories would be made to contribute to the fund according to their capacities to choose between safety and accident costs. Such a New Zealand-type plan (expanded so that payments into the fund, to a far greater extent than in that plan, would reflect capacity to opt for or against safety) may best combine our society's mixed goals in accident law. See generally James A. Henderson, Jr., The New Zealand Accident Compensation Reform, 48 U. Chi. L. Rev. 781 (1981); Geoffrey Palmer, Compensation for Incapacity (1979).
} 
In this paper, we have tried to outline the meanings and possible reasons for using the various tests of liability commonly employed in torts today. Each of them-not surprisingly and despite diatribes by critics-is a rational approach and could, in the right circumstances, on the right facts, be desirable. Which mixture, if any, of the ex ante Learned Hand test (1), the ex ante strict liability test (2), the ex post Learned Hand test (3), and the ex post strict liability test (4) proves best in our circumstances remains to be seen. 
HeinOnline -- 14 J. Legal Stud. 6281985 